\title{
Phytochemical screening, antioxidant study and hematinic property of Mojeaga herbal remedy using animal model
}

\author{
MacDonald Idu', Monday Ojeaga Alugeh², Micheal Ojeaga Alugeh² and Benjamin Ogunma Gabriel ${ }^{*}$
}

\begin{abstract}
Background: Plants have been used as medicine since ancient time and contributed immensely to health care delivery system globally. The aim of this study was to evaluate the phytoconstituents, antioxidant and hematinic property of Mojeaga herbal remedy (Alchornea cordifolia, Sorghum bicolor and Pennisetum glaucum) in animal model. Standard protocols were used to analyze the qualitative and quantitative phytochemical, gas chromatography mass spectrum (GC-MS), and in vitro antioxidant studies (1, 1-diphenyl-2-picrylhydrazyl) (DPPH), ferric reducing antioxidant power (FRAP) and total antioxidant capacity were also used to assess these plants. Ninety Wistar rats of both sexes were selected for this study. They were administered with $40 \mathrm{mg} / \mathrm{kg}$ phenylhydrazine hydrochloride to induce anemia for 5 days afterward treated with oral dose of $0.5,1.0$ and $2.0 \mathrm{ml} / \mathrm{kg}$ Mojeaga herbal remedy for 10 days. Hematological, CD4 and CD8, and histology of the blood and bone marrow were analyzed.
\end{abstract}

Results: The phytochemical screening showed the presence of flavonoids, alkaloids, tannins, saponins, cardiac glycosides, terpenoids and phenol. Flavonoids and phenol were more in abundant (917 and $1445 \mathrm{mg} / \mathrm{kg}$ ). The GCMS analysis shows the presence of disulfide, dimethyl, 2-Methoxy-4-vinylphenol, 1-Dodecanol, 10-Phenyldecanoic acid, 8-Phenyloctanoic acid, n-Hexadecanoic acid and 15-Hydroxypentadecanoic acid. The antioxidant scavenging property showed the potential capacity of the herbal remedy to scavenge free radicals against oxidative stress at 24\%, 53.8\% 1609.9 $\mu \mathrm{M}$ Fe II/ g extract when compared with ascorbic acid. The hematological indexes showed a significant increase in red blood cells, hemoglobin, hematocrit mean corpuscular hemoglobin, mean corpuscular hemoglobin concentrations, mean corpuscular volume, CD4 and CD8 count at day 10 of the male and female rats with the values of $\operatorname{RBC}\left(6.72,7.34,7.10 \times 10^{6} / \mathrm{ul}\right)\left(6.78,6.75,6.79 \times 10^{6} / \mathrm{ul}\right)$, hematocrit $(47.8,51.5,49.75 \%)(48.05,44.80,44.60 \%)$ and hemoglobin $(16.5,18.05,17.1 \mathrm{~g} / \mathrm{dl})(16.6,15.6,15.75 \mathrm{~g} / \mathrm{dl})$ when compared with the control $(p<0.05)$. The histo-architectural structure of the bone marrow showed a stimulating effect of myeloid/erythroid cell ratio $>60$ in the treatment groups when compared with $40 \mathrm{mg} / \mathrm{kg}$ phenylhydrazine alone.

Conclusions: In conclusion, mojeaga herbal remedy elicited hematinic property that validated the folklore report; hence, further evaluation will be required.

Keywords: Phytochemicals, Antioxidants, Hematinic, Mojeaga, Herbal remedy

\footnotetext{
*Correspondence: alexthemain076@gmail.com

1 Phytomedicine Unit, Department of Plant Biology and Biotechnology,

University of Benin, PMB 1154, Benin City, Edo State, Nigeria

Full list of author information is available at the end of the article
}

\section{Background}

Using plants as sources of medicine serves as the oldest health care provider known to man. Herbs have been used by all cultures throughout history and have remained an integral part of the development of modern civilization [1]. The World Health Organization estimated up to $80 \%$ of the world population in developing 
countries depends on locally available plant resources for their primary health care, since Western pharmaceuticals are often expensive, inaccessible or unsuitable [2]. Plant phytochemicals have shown a pivotal pipeline in pharmaceutical discovery [2]. It stimulated scientific interest in biological activities because of their phytoconstituents [3-5]. They are used for several curative purposes because of their therapeutic importance [2]. According to the WHO, herbal medicines are finished, labeled medicinal products that contain active ingredients.

Alchornea cordifolia is a perennial evergreen shrub that belongs to the family Euphorbiaceae [6,7]. It is known as Dove wood in English, "epa" in Yoruba, "bambami" in Hausa, "ubebe" in Igbo and "uwonmwe" in Edo [8]. Studies have validated its ethnopharmacological uses with characterized pharmacologically active molecules [9]. Infusion of the leaves is used in the treatment of respiratory problems such as sore throat, cough, bronchitis and intestinal problems such as gastric ulcers, diarrhea, amoebic dysentery and worms. Poultice of the leaves is also used to treat wounds. Application of the leaves and root bark of Alchornea cordifolia is used in treatment of leprosy and as antidote for snake bite [10]. Alchornea cordifolia root and bark are used to increase sexual performances among the people of Congo in Africa sub-region [11]. In Nigeria, it is used to treat gonorrhoea, yaws, rheumatic pain and cough [12].

Sorghum bicolor leaves are typically green, glasslike and flat and not as broad as maize leaves. It belongs to the grass family Poaceae [13]. Sorghum bicolor is locally known as 'oka pupa' in the Southern part of Nigeria. $S$. bicolor grain is higher in protein and lower in fat content than corn and this is partly responsible for its hemopoietic ability [14]. It has been reported that sorghum can be used as anti-abortive, cyanogenetic, demulcent, diuretic, emollient, in-toxicant and poison. Sorghum is a folk remedy for cancer, epilepsy, flux, stomach ache, diarrhea, tubercular swellings treatment carcinogenic [15-18]. Recent focus has been on the leaf sheath of S. bicolor used as herbal remedy for anemia and boosting effect on blood concentration hematinic potentials, which serves as blood tonics[19, 20].

Pennisetum glaucum is commonly called Pearl millet, which belongs to a section of the Paniceae family known as Poaceae $[21,22]$. It helps to increase $\mathrm{Hb}$ high iron content $(8 \mathrm{mg} / 100 \mathrm{~g})$ and high zinc content $(3.1 \mathrm{mg} / 100 \mathrm{~g})$. It is effective in the management of Constipation by dealing with constipation with High fiber $(1.2 \mathrm{~g} / 100 \mathrm{~g})$. It combated cancer, promoting anti-cancer property via inhibition of tumor development [23]. Also, it helps in regulating diabetes by helping in the dealing with diabetes with Low glycemic index. It is as well useful for antiallergic Gluten-free, diarrhea via probiotic treatment of Lactic acid bacteria. It promotes nutriceutical content of Flavonoids, phenolics Omega-3 fatty acids. Pearl millet has a large amount of phosphorus [23].

Anemia is a medical condition characterized by lowered hemoglobin level. There are over 400 types of anemia, with hemolytic anemia being the most frequent [24]. More than half of the world's population experience some forms of anemia in their life time [25]. The incidence of anemia is higher in the third world than in developed countries [26]. A study in a rural population of Nigeria reported that $19.7 \%$ of the children were anemic [27]. Such prevalence has been attributed to various aggravating factors such as poor nutrition, high prevalence of blood parasites, for example, Plasmodium, Trypanosome and helminthes infections [26]. Prolonged use of non-steroidal anti-inflammatory drugs and exposure to toxic chemicals such as phenylhydrazine has also been implicated to cause the condition [28]. Because of the high prevalence and possibility of even further increase [25], there is the need to prevent it or seek for more cost effective and better treatment strategies. Therefore, this study investigated the phytochemicals contents, antioxidant property and hematinic potential of Mojeaga herbal remedy (Alchornea cordifolia, Sorghum bicolor, Pennisetum glaucum) leave preparation.

\section{Methods}

\subsection{Collection of plant material}

Alchornea cordifolia, Sorghum bicolor, Pennisetum glaucum were collected from Ikpoba Okha Local Government Area of, Benin City, Edo State, Nigeria. They were identified and authenticated by Dr. O. Timothy of the Department of Plant Biology and Biotechnology, University of Benin, Edo State, Nigeria with voucher numbers UBH-A192; UBH-A199; UBH-A247.

\subsection{Preparation of plant material}

The leaves of the three plants were washed, air-dried separately for 21 days. The dried leaves were pulverized into powder using the British milling machine. The weights of the various plants powdered leaves were separately taken, and ratio 1:1:1 was used for the plant mixture, summing up to $(120,000 \mathrm{~g}) .20 \mathrm{~L}$ of distilled water was used in the maceration of the extract for $72 \mathrm{~h}$ in a shaker. The filtrate was concentrated via vacuum pump, and the extract was stored in a sterile container and kept for further use.

\subsection{Qualitative and quantitative phytochemical analysis}

Qualitative and quantitative phytochemical screening of the aqueous leaves preparation of Mojeaga herbal remedy was carried out using standard methods [29, 30]. The extract was screened for the presence of alkaloids, 
Table 1 Qualitative phytochemicals screening of Mojeaga herbal remedy

\begin{tabular}{ll}
\hline Phytochemicals & $\begin{array}{l}\text { Mojeaga } \\
\text { herbal } \\
\text { remedy }\end{array}$ \\
\hline Flavonoids & + \\
Cardiac glycosides & + \\
Saponins & + \\
Steroids & - \\
Terpenoids & + \\
Phenols & + \\
Alkaloids & + \\
Tannins & + \\
\hline
\end{tabular}

Table 2 Quantitative phytochemicals screening of Mojeaga herbal remedy

\begin{tabular}{lc}
\hline Phytochemicals & $\begin{array}{l}\text { Mojeaga herbal } \\
\text { remedy } \mathbf{~} \mathbf{g} / \mathbf{1 0 0} \mathbf{g}\end{array}$ \\
\hline Alkaloids & $6.00 \pm 0.00$ \\
Saponins & $7.00 \pm 1.00$ \\
Tannins & $267.00 \pm 0.01$ \\
Flavonoids & $917.00 \pm 0.93$ \\
Phenol & $1445.00 \pm 1.17$ \\
\hline
\end{tabular}

KEY: $+=$ Detected, $-=$ Not detected

Table 3 Phytoconstituents identified in Mojeaga herbal remedy on GC-MS study

\begin{tabular}{|c|c|c|c|c|c|}
\hline S. No & RT (Min) & Phyto-constituents & $M / F$ & $\mathrm{M} / \mathrm{W}$ & $\% \mathrm{PA}$ \\
\hline 1 & 6.445 & Disulfide, dimethyl & $\mathrm{C}_{2} \mathrm{H}_{6} \mathrm{~S}_{2}$ & 94 & 0.04 \\
\hline 2 & 11.796 & 2-Methoxy-4-vinylphenol & $\mathrm{C}_{9} \mathrm{H}_{10} \mathrm{O}_{2}$ & 150 & 0.28 \\
\hline 3 & 13.592 & 1-Dodecanol & $\mathrm{C}_{12} \mathrm{H}_{26} \mathrm{O}$ & 186 & 0.85 \\
\hline 4 & 14.733 & 10-Phenyldecanoic acid & $\mathrm{C}_{16} \mathrm{H}_{24} \mathrm{O}_{2}$ & 248 & 0.12 \\
\hline 5 & 15.811 & 1-Hexadecanol & $\mathrm{C}_{16} \mathrm{H}_{34} \mathrm{O}$ & 242 & 0.75 \\
\hline 6 & 16.225 & Methoxyacetic acid, pentadecyl ester & $\mathrm{C}_{18} \mathrm{H}_{36} \mathrm{O}_{3}$ & 300 & 0.27 \\
\hline 7 & 16.842 & 9-Octadecenoic acid (Z)-, phenylmethyl ester & $\mathrm{C}_{25} \mathrm{H}_{40} \mathrm{O}_{2}$ & 372 & 0.16 \\
\hline 8 & 16.926 & Ethyl 14-methyl-hexadecanoate & $\mathrm{C}_{19} \mathrm{H}_{38} \mathrm{O}_{2}$ & 298 & 0.10 \\
\hline 9 & 17.418 & Cyclopentadecanone & $\mathrm{C}_{15} \mathrm{H}_{28} \mathrm{O}$ & 224 & 0.19 \\
\hline 10 & 17.833 & 8-Phenyloctanoic acid & $\mathrm{C}_{14} \mathrm{H}_{20} \mathrm{O}_{2}$ & 220 & 0.47 \\
\hline 11 & 18.178 & Hexadecanoic acid, methyl ester & $\mathrm{C}_{17} \mathrm{H}_{34} \mathrm{O}_{2}$ & 270 & 0.92 \\
\hline 12 & 18.598 & n-Hexadecanoic acid & $\mathrm{C}_{16} \mathrm{H}_{32} \mathrm{O}_{2}$ & 256 & 6.72 \\
\hline 13 & 18.797 & Hexadecanoic acid, ethyl ester & $\mathrm{C}_{18} \mathrm{H}_{36} \mathrm{O}_{2}$ & 284 & 7.28 \\
\hline 14 & 19.815 & 9,12-Octadecadienoic acid, methyl ester & $\mathrm{C}_{19} \mathrm{H}_{34} \mathrm{O}_{2}$ & 294 & 2.16 \\
\hline 15 & 19.875 & 9-Octadecenoic acid (Z)-, methyl ester & $\mathrm{C}_{19} \mathrm{H}_{36} \mathrm{O}_{2}$ & 296 & 2.31 \\
\hline 16 & 19.996 & Phytol & $\mathrm{C}_{20} \mathrm{H}_{40} \mathrm{O}$ & 296 & 1.07 \\
\hline 17 & 20.132 & Cyclopentanetridecanoic acid, methyl ester) & $\mathrm{C}_{19} \mathrm{H}_{36} \mathrm{O}_{2}$ & 296 & 0.51 \\
\hline 18 & 20.442 & 9,12-Octadecadienoic acid (Z,Z)- & $\mathrm{C}_{18} \mathrm{H}_{32} \mathrm{O}_{2}$ & 280 & 15.17 \\
\hline 19 & 20.556 & 9,12-Octadecadienoic acid (Z,Z)- & $\mathrm{C}_{18} \mathrm{H}_{32} \mathrm{O}_{2}$ & 280 & 16.54 \\
\hline 20 & 20.621 & (E)-9-Octadecenoic acid ethyl ester & $\mathrm{C}_{20} \mathrm{H}_{38} \mathrm{O}_{2}$ & 310 & 12.92 \\
\hline 21 & 20.682 & 9,12-Octadecadienoic acid (Z,Z)- & $\mathrm{C}_{18} \mathrm{H}_{32} \mathrm{O}_{2}$ & 280 & 4.19 \\
\hline 22 & 20.772 & 6,9,12-Octadecatrien-1-ol & $\mathrm{C}_{18} \mathrm{H}_{32} \mathrm{O}$ & 264 & 3.56 \\
\hline 23 & 20.900 & Octadecanoic acid, ethyl ester & $\mathrm{C}_{20} \mathrm{H}_{40} \mathrm{O}_{2}$ & 312 & 6.70 \\
\hline 24 & 21.224 & Phenacyl 11-octadecenoate & $\mathrm{C}_{26} \mathrm{H}_{40} \mathrm{O}_{3}$ & 400 & 2.11 \\
\hline 25 & 22.243 & 15-Hydroxypentadecanoic acid & $\mathrm{C}_{15} \mathrm{H}_{30} \mathrm{O}_{3}$ & 258 & 1.88 \\
\hline 26 & 22.884 & 8,11,14-Eicosatrienoic acid, (Z,Z,Z)- & $\mathrm{C}_{20} \mathrm{H}_{34} \mathrm{O}_{2}$ & 306 & 0.51 \\
\hline 27 & 23.051 & 9,12-Octadecadienoic acid (Z,Z)- & $\mathrm{C}_{18} \mathrm{H}_{32} \mathrm{O}_{2}$ & 280 & 0.52 \\
\hline 28 & 24.202 & 8,11,14-Eicosatrienoic acid, $(Z, Z, Z)-$ & $\mathrm{C}_{20} \mathrm{H}_{34} \mathrm{O}_{2}$ & 306 & 2.61 \\
\hline 29 & 24.247 & 9,12-Octadecadienoic acid (Z,Z)- & $\mathrm{C}_{18} \mathrm{H}_{32} \mathrm{O}_{2}$ & 280 & 3.10 \\
\hline 30 & 24.486 & 15-Hydroxypentadecanoic acid & $\mathrm{C}_{15} \mathrm{H}_{30} \mathrm{O}_{3}$ & 258 & 1.32 \\
\hline 31 & 24.662 & Hexadecanoic acid, 2-hydroxy-1-(hydroxymethyl) & $\mathrm{C}_{19} \mathrm{H}_{38} \mathrm{O}_{4}$ & 330 & 1.09 \\
\hline 32 & 26.292 & 9-Octadecenoic acid (Z)-, 2-hydroxy-1-(hydroxymethyl) & $\mathrm{C}_{21} \mathrm{H}_{40} \mathrm{O}_{4}$ & 356 & 3.57 \\
\hline
\end{tabular}

$R T$ Retention time; $M / F$ molecular formular; $M W$ molecular weight; $P A$ peak area 
Table 4 Biological important peaks of GCMS found in Mojeaga herbal remedy

\begin{tabular}{|c|c|c|c|}
\hline Peak no & Name & Structure & Biological activities \\
\hline 12 & n-Hexadecanoic acid & & Haemolytic anemia, antioxidant \\
\hline 13 & Hexadecanoic acid, ethyl ester & & Antioxidant, anemia, hypocholesterol \\
\hline $18-19$ & 9,12-Octadecadienoic acid (Z,Z)- & $\mathrm{OH}$ & $\begin{array}{l}\text { Anti-inflammatory, antiarthritic, } \\
\text { hepatoprotective, anticoronary, anti- } \\
\text { histamic }\end{array}$ \\
\hline 20 & E)-9-Octadecenoic acid ethyl ester & & Steroids, fertility \\
\hline 23 & Octadecanoic acid, ethyl ester & & Antifungi, antitumor, antibacteria/ \\
\hline
\end{tabular}

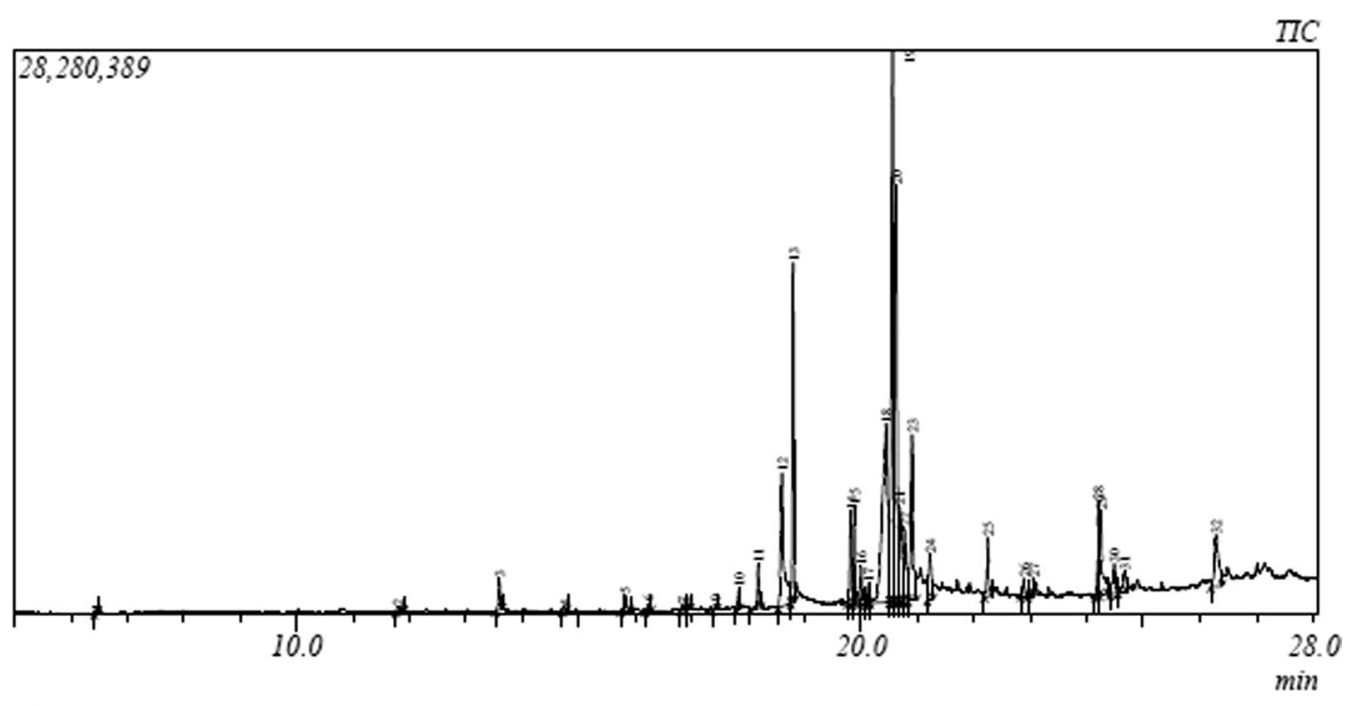

Fig. 1 GCMS of Mojeaga herbal remedy showed vital peaks
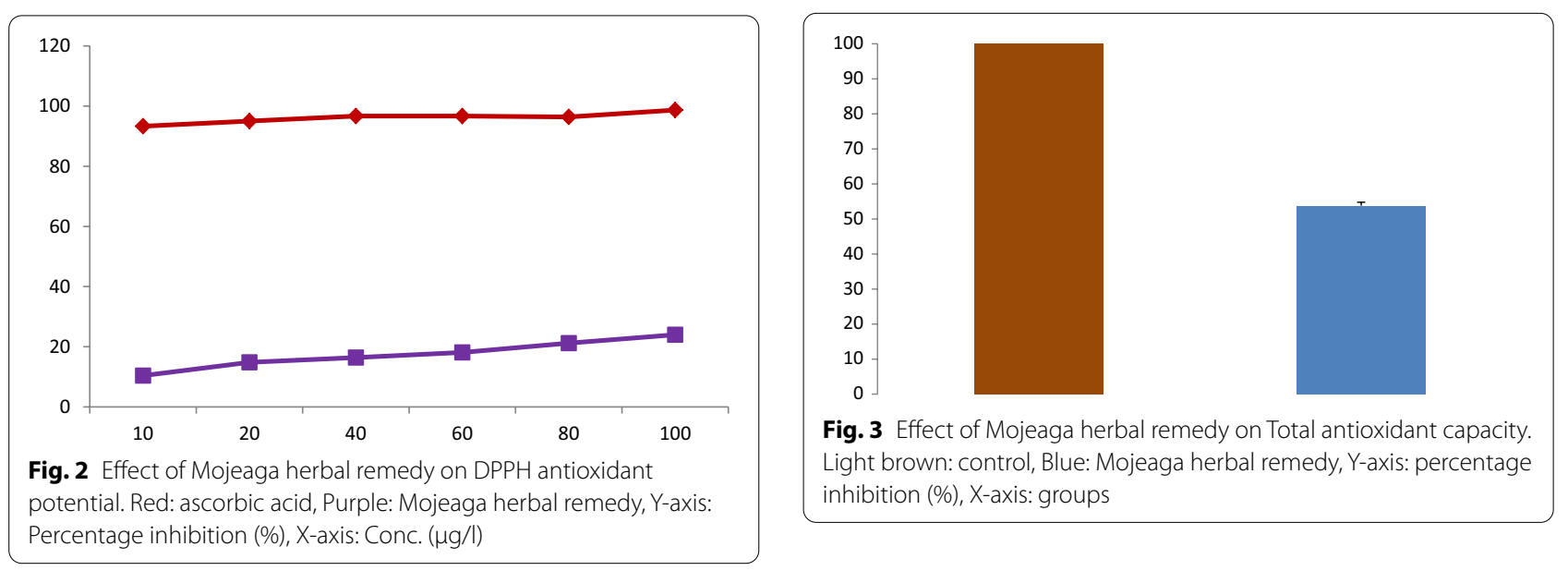


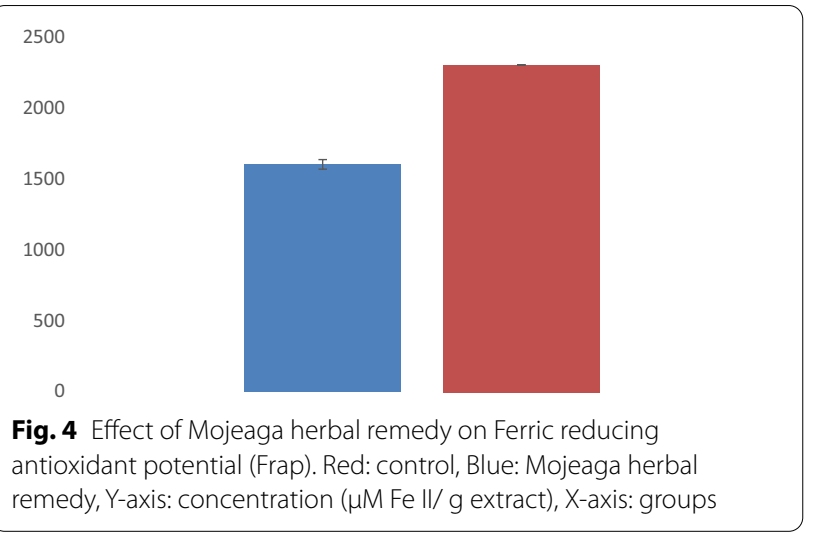

flavonoids, phenolic compounds, tannins, terpenoids, saponins, and glycosides.

\subsection{In vitro antioxidant activity}

The free radical scavenging capacity of the extract against 1, 1-diphenyl-2-picrylhydrazyl (DPPH) radical was determined by the method of Brand-Williams et al. [31, 32]; the phosphomolybdate reduction capacity was estimated using the method described by Prieto et al. [33], and the ferric reducing antioxidant power (FRAP) assay was carried out using a modified method of Ruch et al. [34].

\subsection{Gas chromatography-mass spectroscopy (GC-MS)}

The phytocomponents of Mojeaga herbal remedy was identified using gas chromatography-mass spectroscopy
(GC-MS) detection system. The GC-MS analysis was accompanied using an Agilent 19091 s GC system. The capillary column used was 933HP-1MS $(30 \times 250 \mu \mathrm{m}$; film thickness of $0.25 \mu \mathrm{m}$; J \& W Scientific, USA). The temperature program was set at as follows: initial temperature $60{ }^{\circ} \mathrm{C}$ held for $1.5297 \mathrm{~min}, 30{ }^{\circ} \mathrm{C}$ per min to $150{ }^{\circ} \mathrm{C}$ for $5 \mathrm{~min}, 30{ }^{\circ} \mathrm{C}$ per min to $250{ }^{\circ} \mathrm{C}$ held for $8 \mathrm{~min}$. The total run time was $21.333 \mathrm{~min}$, while the flow rate of Helium as a carrier gas was $0.79653 \mathrm{~mL} / \mathrm{min}$. The MS system was performed in electron ionization (EI) mode with Selected Ion Monitoring (SIM). The ion source temperature and quadruple temperature were set at $230{ }^{\circ} \mathrm{C}$ and $150{ }^{\circ} \mathrm{C}$, respectively.

Identification of phytocomponents was performed by comparison of the retention time and mass of the eluted compounds with those of authentic standards spectra using searches on the database of National Institute Standard and Technology (NIST).

\subsection{Experimental animals}

Ninety (90) healthy Wistar rat (males and females) weighed 180-250 g. These animals were bred in Biochemistry animal house, University of Benin, Benin City. They were housed in a well-ventilated woody cages with male and female in a different compartment under normal laboratory conditions (12 h light/dark cycle: $23 \pm 2{ }^{\circ} \mathrm{C}$ ) and fed with standard diet. Food and water were given free choice (ad libitum) to all animals used for the experiments for 14 days acclimatization period. They were handled according to standard protocols all through

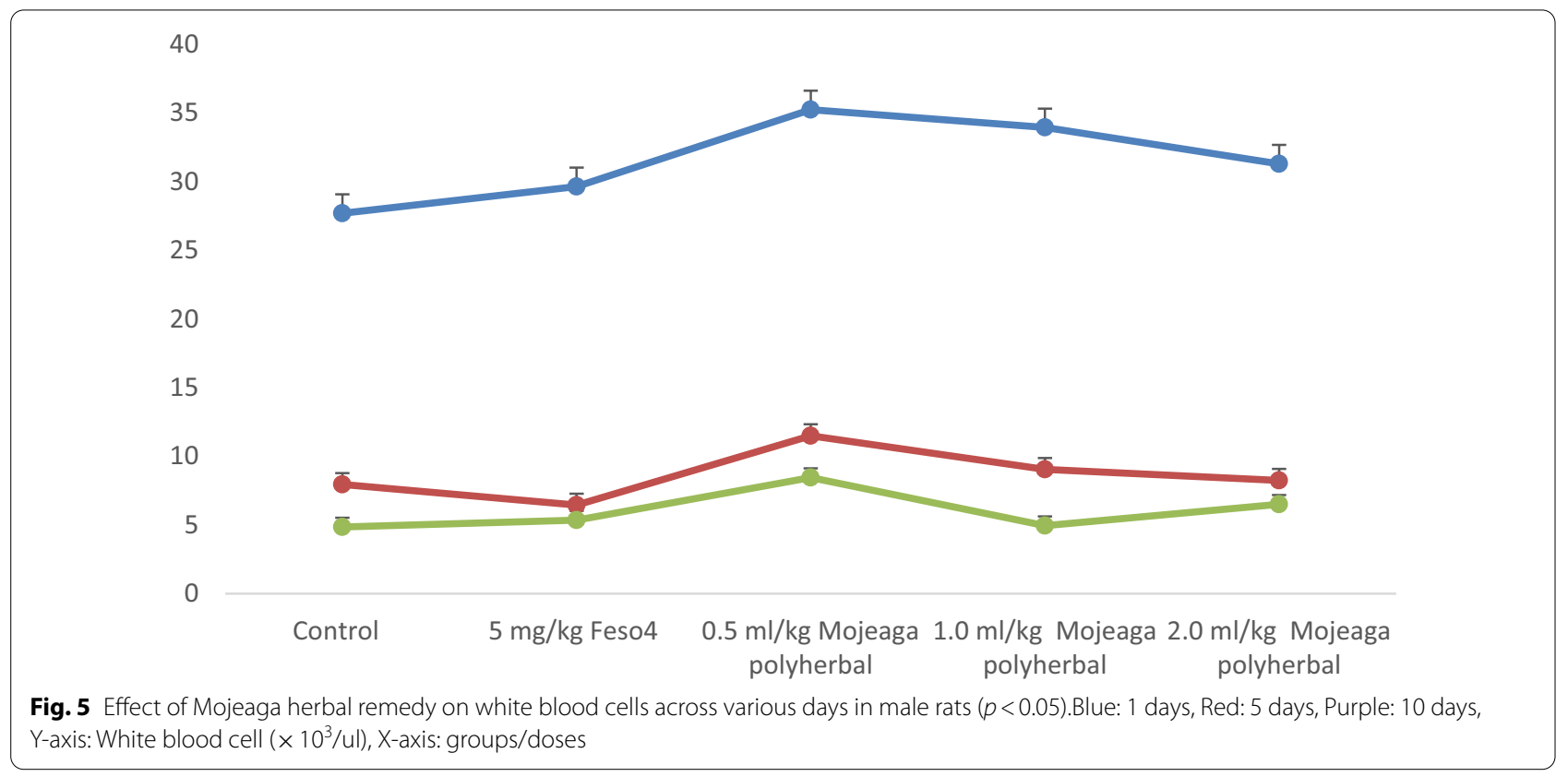




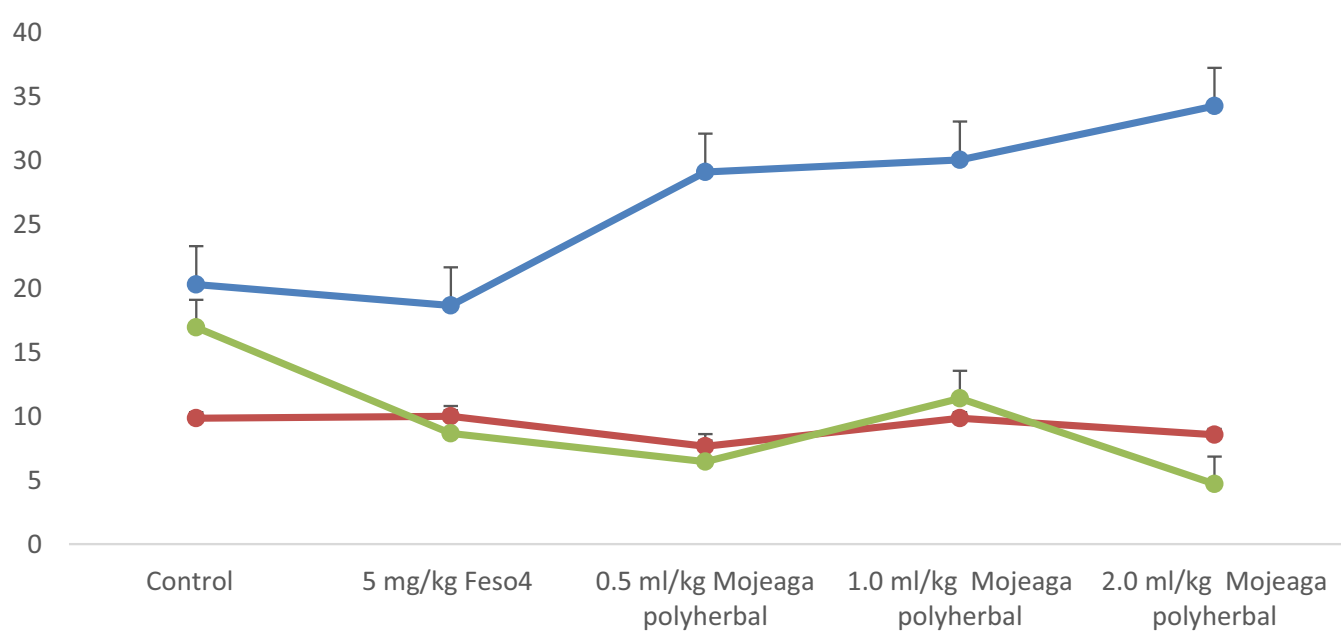

Fig. 6 Effect of Mojeaga herbal remedy on white blood cells across various days in female rats $(p<0.05)$. Blue: ----1 days, Red: 5 days, Purple: 10 days, Y-axis: white blood cell $\left(\times 10^{3} / \mathrm{ul}\right)$, X-axis: groups/doses

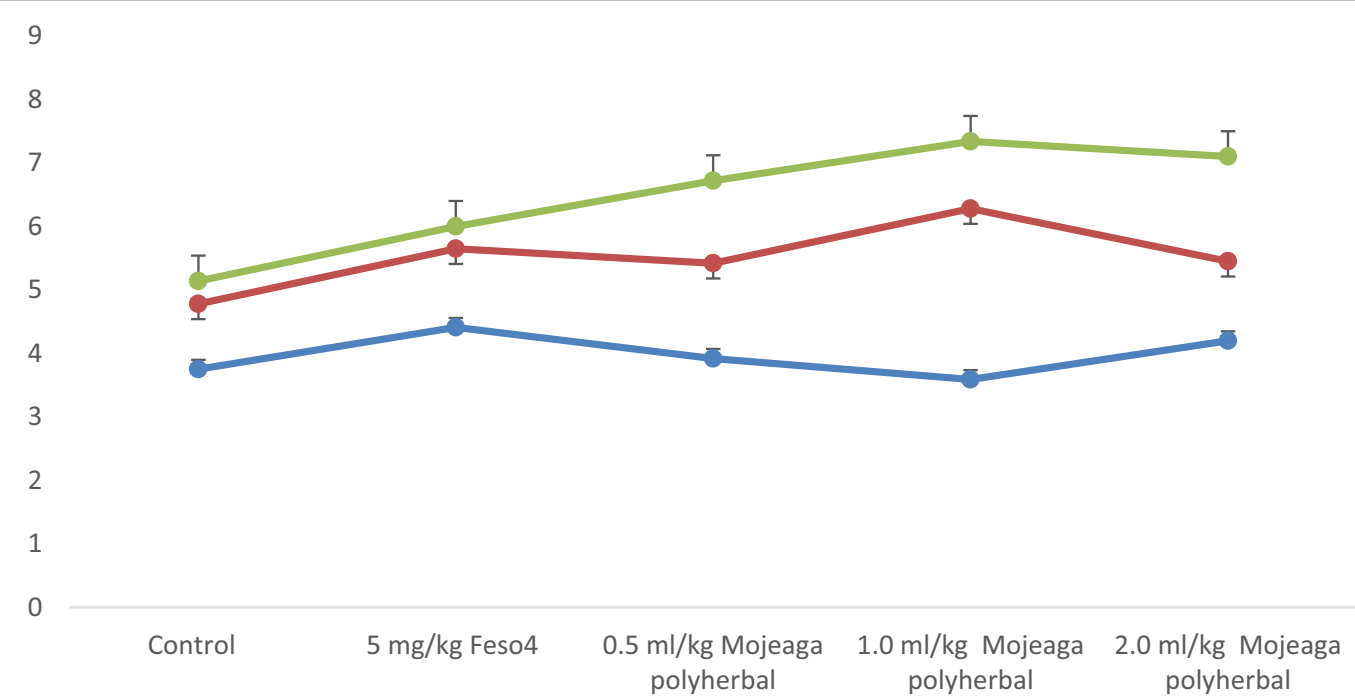

Fig. 7 Effect of Mojeaga herbal remedy on red blood cells across various days in male rats $(p<0.05)$. Red: 5 days, Purple: 10 days, Y-axis: red blood cells $\left(\times 10^{6} / \mathrm{ul}\right)$, X-axis: groups/doses

the experimental period (10 consecutive days). The animals were properly handled using the ethics of Laboratory animals' approval from the ethical committee of Faculty of Life Sciences with the ethical number LS19214.

\subsection{Experimental design}

Six (10) groups of 18 animals per group having male and female animals were separately treated as schedule. Group A male and female received $(5 \mathrm{mg} / \mathrm{kg}$ orally (p.o)) Folic acid, group B male and female received phenylhydrazine hydrochloride $(40 \mathrm{mg} / \mathrm{kg} \mathrm{p.o})$ alone, and group $\mathrm{C}, \mathrm{D}$ and $\mathrm{E}$ male and female received aqueous
Mojeaga remedy at $0.5,1$ and $2 \mathrm{~mL} / \mathrm{kg} \mathrm{p.o}$ ). The animals in their respective groups were fasted overnight prior to the administration of phenylhydrazine hydrochloride according to the body weight of each animal for 5 days. Afterward, treatment follows all through 10 consecutive days. Three rats of male and female were killed from each group at days 1, 5 and 10, and the blood samples and bone marrow were analyzed.

\subsubsection{Sample collection}

All the animals were fasted for $8 \mathrm{~h}$, weighed and killed by cervical dislocation $24 \mathrm{~h}$ after the last exposure day. 


$$
8
$$

\section{7}

6

5

4

4
3

2

1

0

$$
\begin{array}{cccc}
5 \mathrm{mg} / \mathrm{kg} \text { Feso4 } & \begin{array}{c}
0.5 \mathrm{ml} / \mathrm{kg} \text { Mojeaga } \\
\text { polyherbal }
\end{array} & \begin{array}{c}
1.0 \mathrm{ml} / \mathrm{kg} \text { Mojeaga } \\
\text { polyherbal }
\end{array} & \begin{array}{c}
2.0 \mathrm{ml} / \mathrm{kg} \text { Mojeaga } \\
\text { polyherbal }
\end{array}
\end{array}
$$

Fig. 8 Effect of Mojeaga herbal remedy on red blood cells across various days in female rats ( $p<0.05)$. Red: 5 days, Purple: 10 days, Y-axis: Red blood cells $\left(\times 10^{6} / \mathrm{ul}\right)$, X-axis: groups/doses

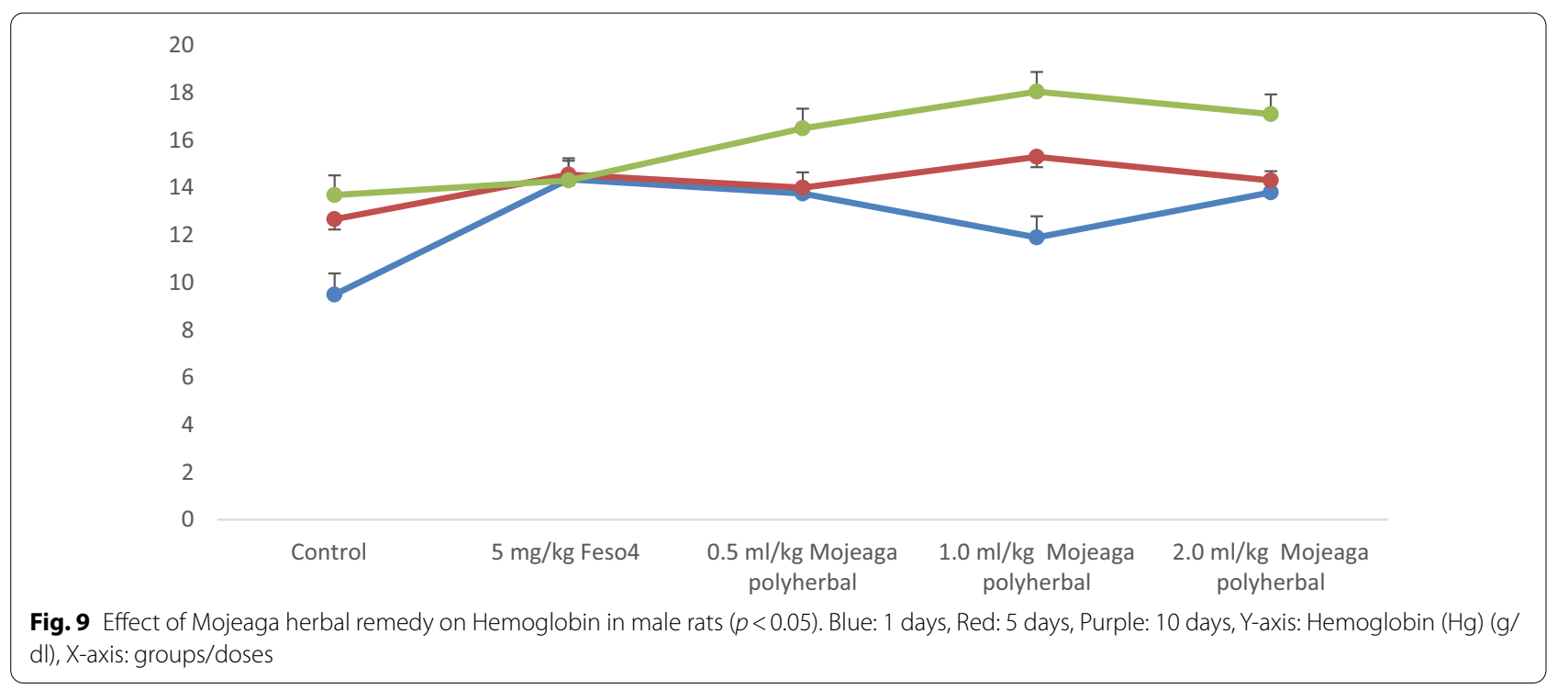

Blood collection was done through aortic puncture, and the serum for biochemical assays was obtained with centrifuge $(1500 \mathrm{rpm}$ for $10 \mathrm{~min})$ after the blood was allowed to clot for $2 \mathrm{~h}$. Blood sample for a hematological analysis was kept in EDTA bottle.

\subsubsection{Bone marrow preparation}

Bone marrow from the femur bones was isolated and decalcified using decalcifying machine, and the slides were prepared from them, and the slide pictures were taken using Photomicrographs at $\times 40$ magnification using a digital camera and were interpreted.

\subsubsection{Hematology assays}

Automated Sysmex KX-21 hematology analyzer (Sysmex Corporation, Kobe, Japan) was used for the determination of red blood cells (RBC), hemoglobin (HGB), hematocrit $(\mathrm{HCT})$, Mean corpuscular volume (MCV), mean corpuscular hemoglobin $(\mathrm{MCH})$, mean corpuscular hemoglobin concentration $(\mathrm{MCHC})$, red cell distribution width (RCDW), white blood cell (WBC), monocytes (MO), lymphocytes (LY), platelets (PLT). Platelets crit (PCT), platelet density width (PDW), mean platelet volume (MPV) and granulocytes (GR). 


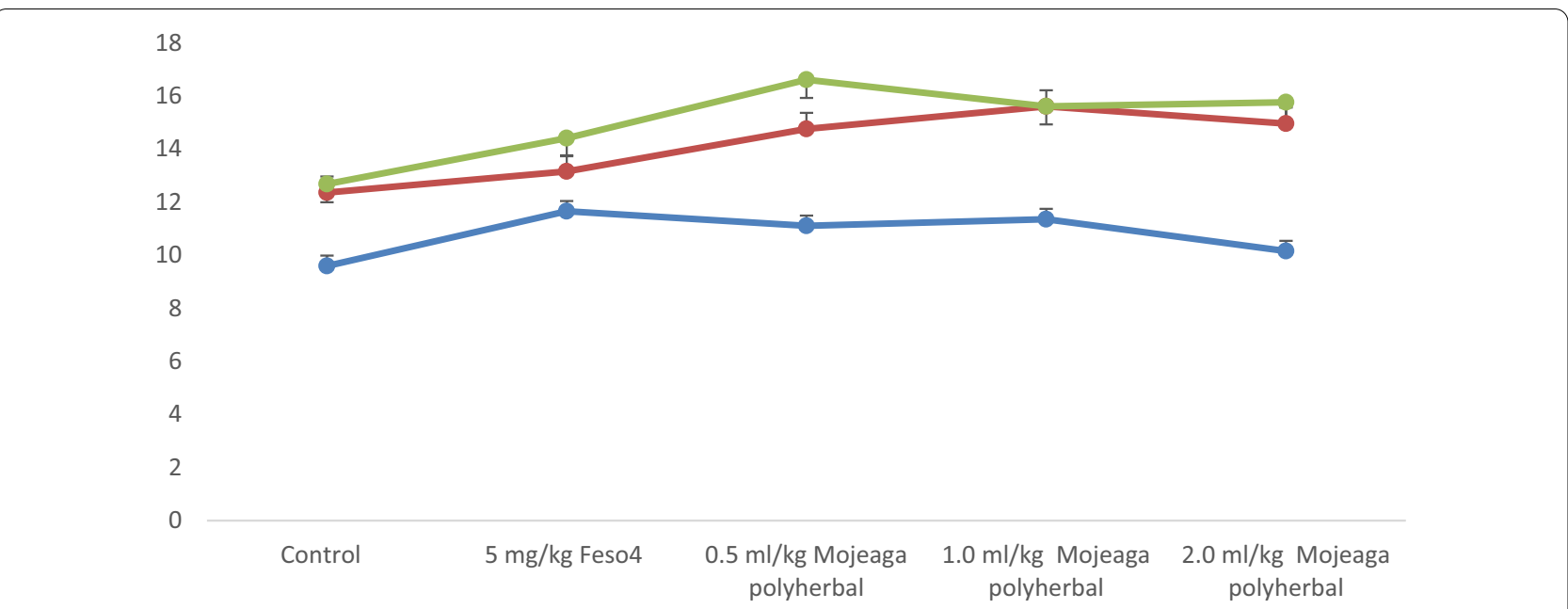

Fig. 10 Effect of Mojeaga herbal remedy on Hemoglobin in female rats ( $p<0.05)$. Blue: 1 days, Red: 5 days, Purple: 10 days, Y-axis: Hemoglobin (Hg) $(\mathrm{g} / \mathrm{dl}), \mathrm{X}$-axis: groups/doses

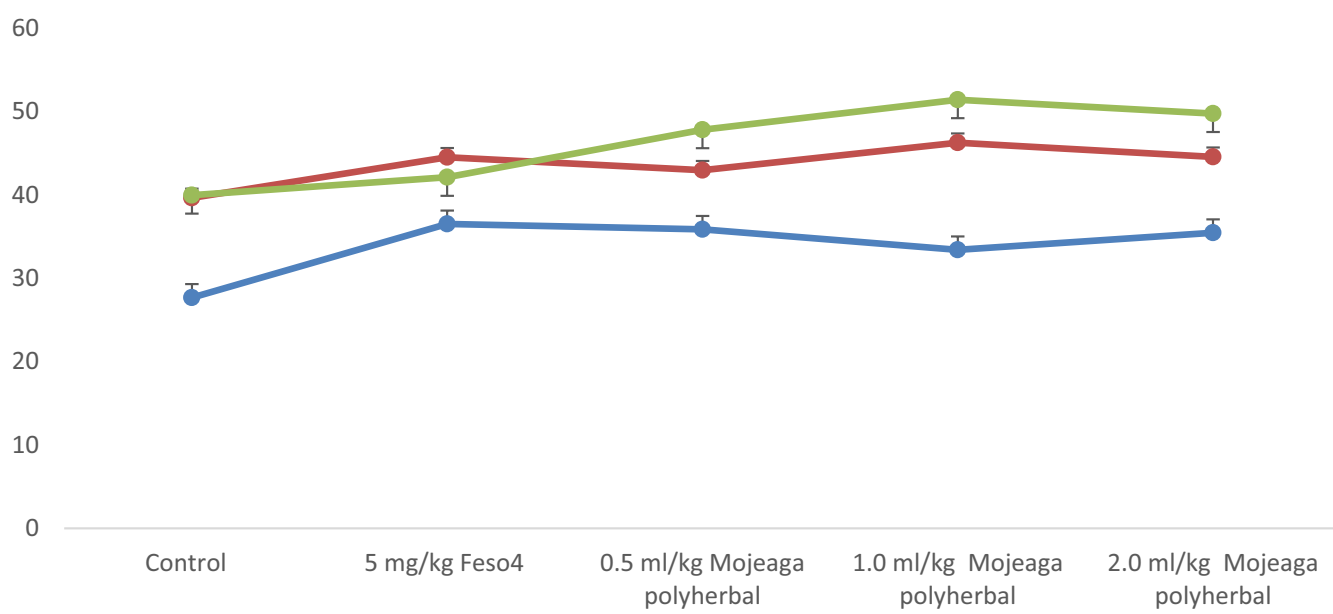

Fig. 11 Effect of Mojeaga herbal remedy on Hematocrite in male rats $(p<0.05)$. Blue: 1 days, Red: 5 days, Purple: 10 days, Y-axis: Hematocrit (HCT) (\%), X-axis: groups/doses

\subsection{Statistical analysis and data presentation}

The statistical analysis was performed using the statistical package for social science (SPSS) for windows, version 16.0 (SPSS Inc., Chicago, IL, USA). The results obtained for the quantitative phytochemical screening, organ-to-body weight ratios, oxidative stress indices, kidney and liver function parameters, hematological assays and gene expressions were expressed as Mean \pm SEM. One-way analysis of variance (ANOVA) test was used to determine significance differences between the treatment groups. Post Hoc Multiple Comparison Test was done using Tukey's HSD (honest significant difference) for these groups. Also, $\mathrm{IC}_{50}$ was calculated using graph pad prism 9 to establish the free radical scavenging and antioxidant potential of the plant extracts. Statistical significance was declared when $p$ value was less than $0.05(p<0.05)$.

\section{Results}

\subsection{Qualitative and quantitative phytochemical analysis of Mojeaga herbal remedy}

The results from the qualitative phytochemical screening showed the presence of flavonoids, alkaloids, tannins, saponins, cardiac glycosides, terpenoids and phenol. In the quantitative study, phenol appears more abundant at $(1445 \mathrm{mg} / 100 \mathrm{~g})$ follows by flavonoids $(917 \mathrm{mg} / 100 \mathrm{~g})$, and the least was alkaloids $(6.0 \mathrm{mg} / 100 \mathrm{~g})$, Tables 1 and 2 . 


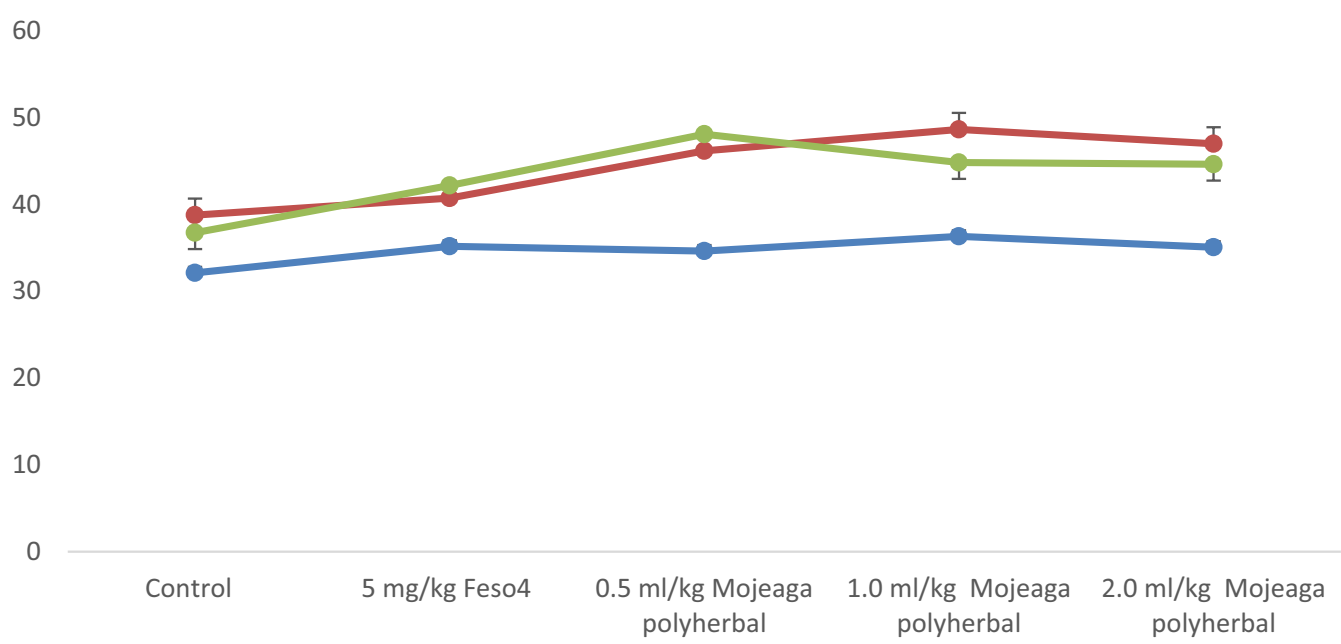

Fig. 12 Effect of Mojeaga herbal remedy on Hematocrit in female rats $(p<0.05)$. Blue: 1 days, Red: 5 days, Purple: 10 days, Y-axis: Hematocrit (HCT) (\%), X-axis: groups/doses

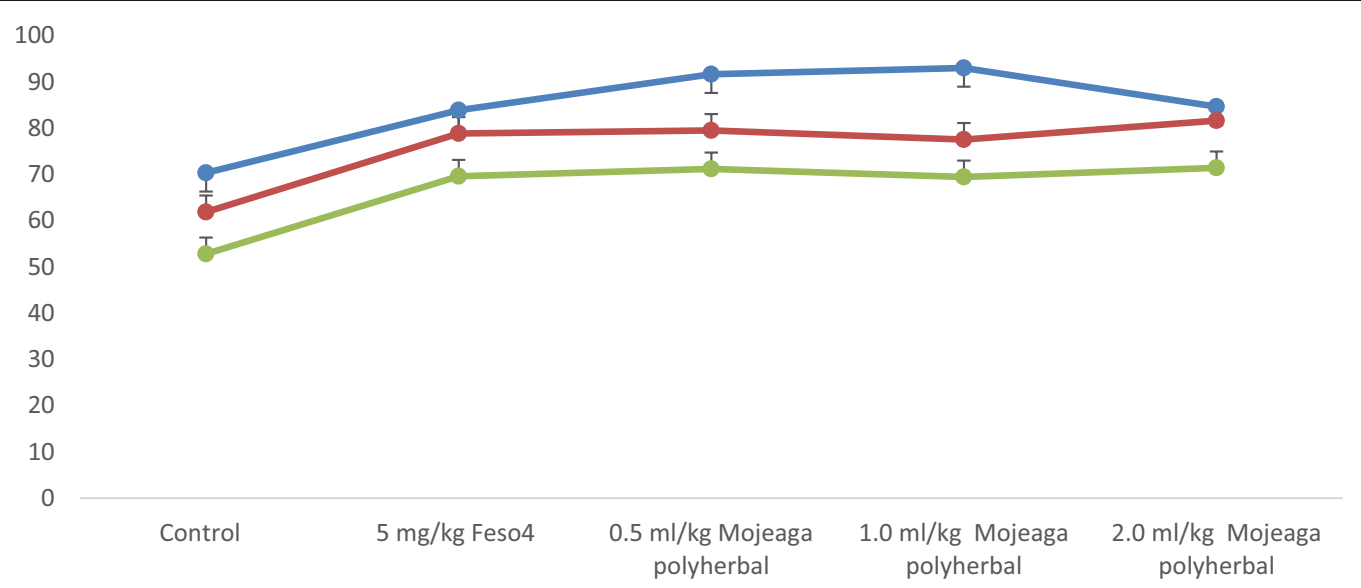

Fig. 13 Effect of Mojeaga herbal remedy on the MCV of male rats $(p<0.05)$. Blue: 1 days, Red: 5 days, Purple: 10 days, Y-axis: Mean Corpuscular Volume (f I), X-axis: groups/doses

\subsection{Gas chromatography mass spectroscopy of Mojeaga herbal remedy}

The phytoconstituents identified from Mojeaga herbal remedy GCMS peak showed the corresponding retention time, molecular formula, molecular weight and relative abundance of the compound (expressed as \% peak area). The compound with the highest peak was 9, 12-Octadecadienoic acid (Z, Z)- and (E)-9-Octadecenoic acid ethyl ester. Other compounds present in low amount (Tables 3, 4 and Fig. 1).

3.3 In vitro antioxidant activity of Mojeaga herbal remedy Mojeaga herbal remedy showed antioxidant scavenging potential as shown in Fig. 2, 3, 4. It elicited radical scavenging effect with a significant decrease in percentage inhibition of DPPH, Total antioxidant capacity and Ferric reducing antioxidant capacity at (24\%, 53.8\% and $1610 \mu \mathrm{M}$ Fe II/ g) when compared with ascorbic acid (98.7\%, 100\% and $2312 \mu \mathrm{M}$ Fe II/ g).

\subsection{Hematological analysis of rats fed with Mojeaga herbal remedy}

Figures 5 and 6 showed a significant increase in the male and female white blood cells across $10 \mathrm{mg} / \mathrm{kg}$ ferrous (iii)-hydroxide and treatment groups in day 1 of the experiment with subsequent increase in days 5 and 10 of the experiment when compared with $40 \mathrm{mg} / \mathrm{kg}$ Phenylhydrazine. 


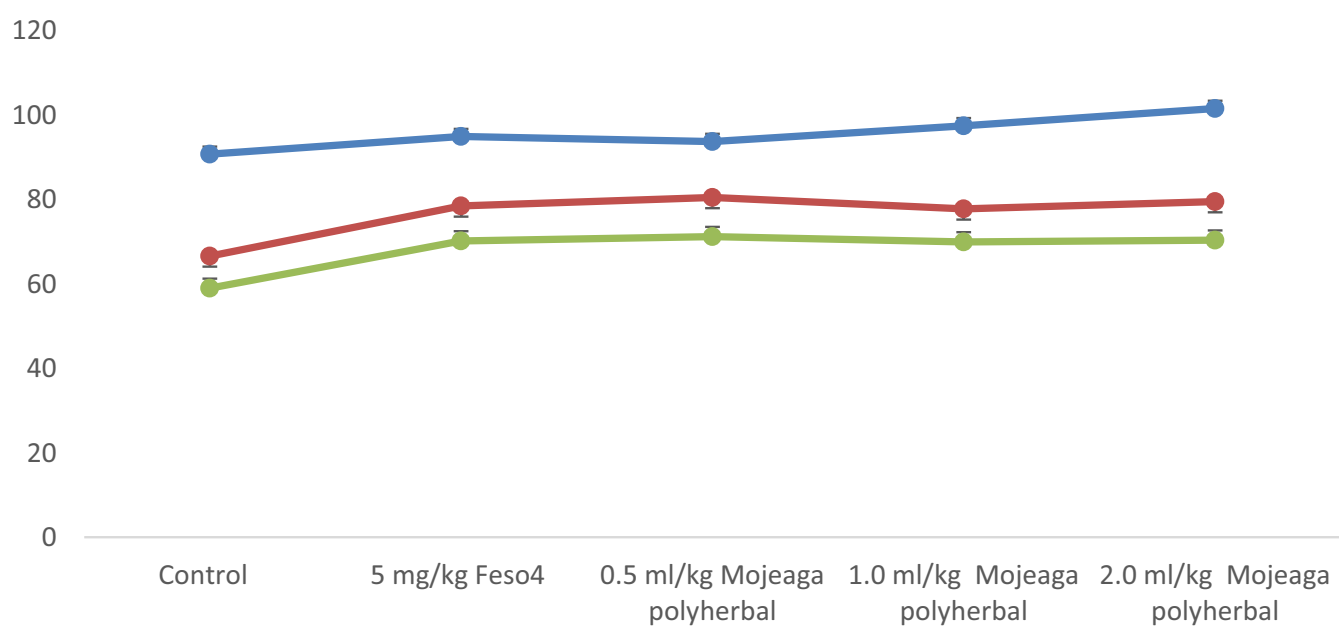

Fig. 14 Effect of Mojeaga herbal remedy on MCV in female rats ( $p<0.05)$. Blue: 1 days, Red: 5 days, Purple: 10 days, Y-axis: Mean Corpuscular Volume $(\mathrm{fl})$, X-axis: groups/doses

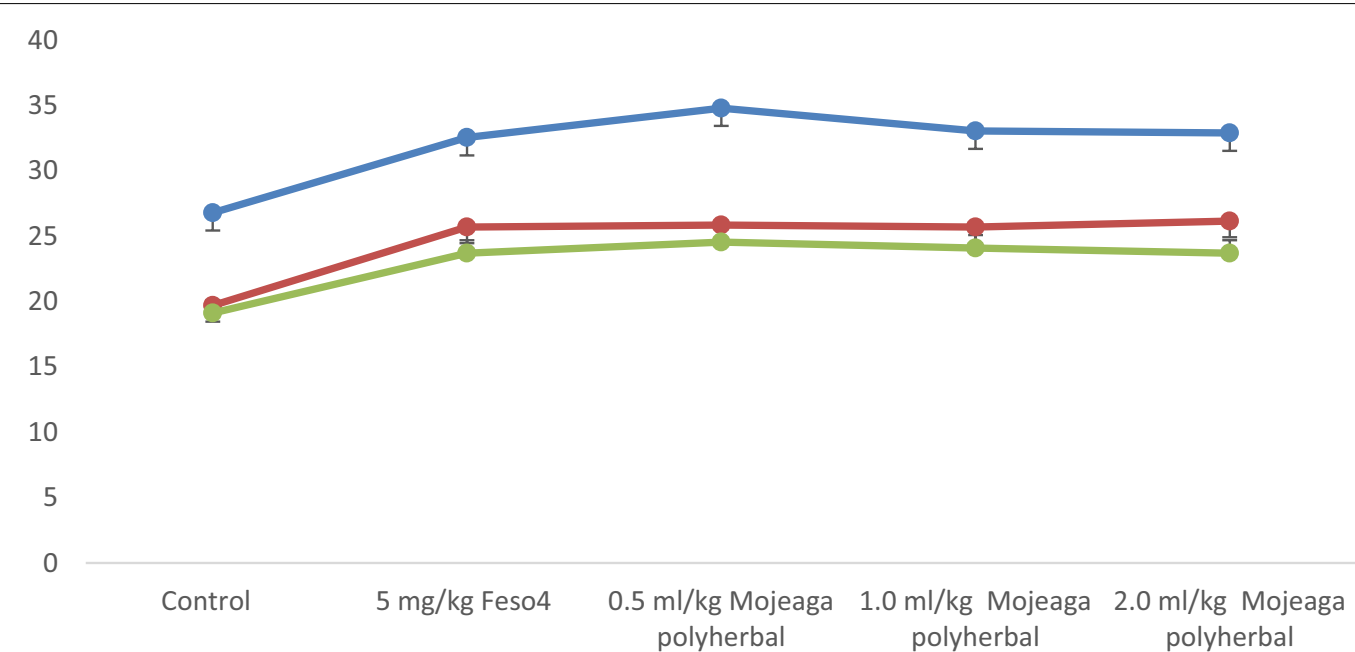

Fig. 15 Effect of Mojeaga herbal remedy on MCH in male rats ( $p<0.05)$. Blue: 1 days, Red: 5 days, Purple: 10 days, Y-axis: Mean Corpuscular hemoglobin (pg), X-axis: groups/doses

Figures 7 and 8 showed slight significant increase in Red blood cell count of male and female animals across $5 \mathrm{mg} / \mathrm{kg}$ ferrous (iii)-hydroxide and treated groups in day 1 of the experiment with subsequent onset of action with a significant increase across days 5 and 10 of the treated groups of Mojeaga herbal remedy when compared with untreated control.

Figures 9 and 10 showed a significant increase in the level of Hemoglobin Concentration $10 \mathrm{mg} / \mathrm{kg}$ ferrous (iii) - hydroxide and treated groups (Mojeaga herbal remedy) in day 1 and subsequently with a significant increase in days 5 and 10 when compared with the control group.
Figures 11 and 12 showed significant decrease in (hematocrit) Packed Cell Volume in male and female animals with $40 \mathrm{mg} / \mathrm{kg}$ Phenylhydrazine, with an increased across $10 \mathrm{mg} / \mathrm{kg}$ ferrous (iii)-hydroxide and treated groups (Mojeaga herbal remedy) in day 1 with a specific significant increase in days 5 and 10.

Figures 13 and 14 showed a significant decrease in Mean Corpuscular Volume in male and female animals with $40 \mathrm{mg} / \mathrm{kg}$ Phenylhydrazine when compared with the increase in $10 \mathrm{mg} / \mathrm{kg}$ ferrous (iii)-hydroxide and treated groups (Mojeaga herbal remedy) in day 1 of the experiment with a specific significant increase in days 5 and 10 . 


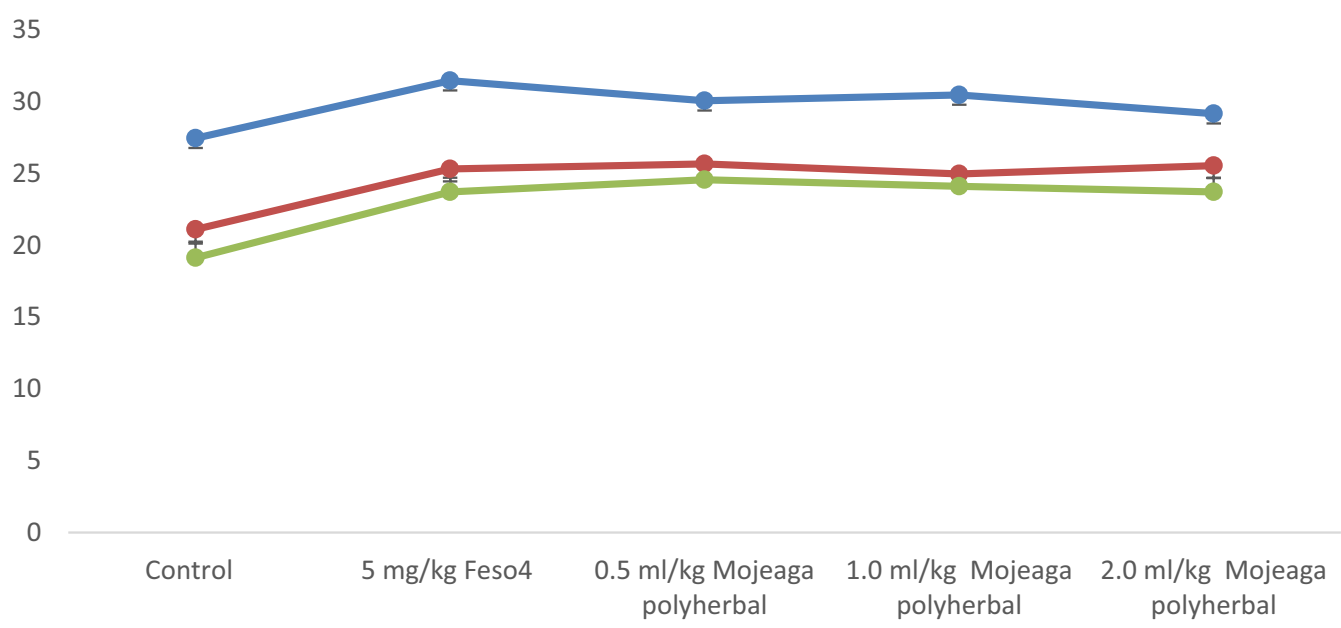

Fig. 16 Effect of Mojeaga herbal remedy on MCH in female rats $(p<0.05)$. Blue: 1 days, Red: 5 days, Purple: 10 days, Y-axis: Mean Corpuscular hemoglobin (pg), X-axis: groups/doses

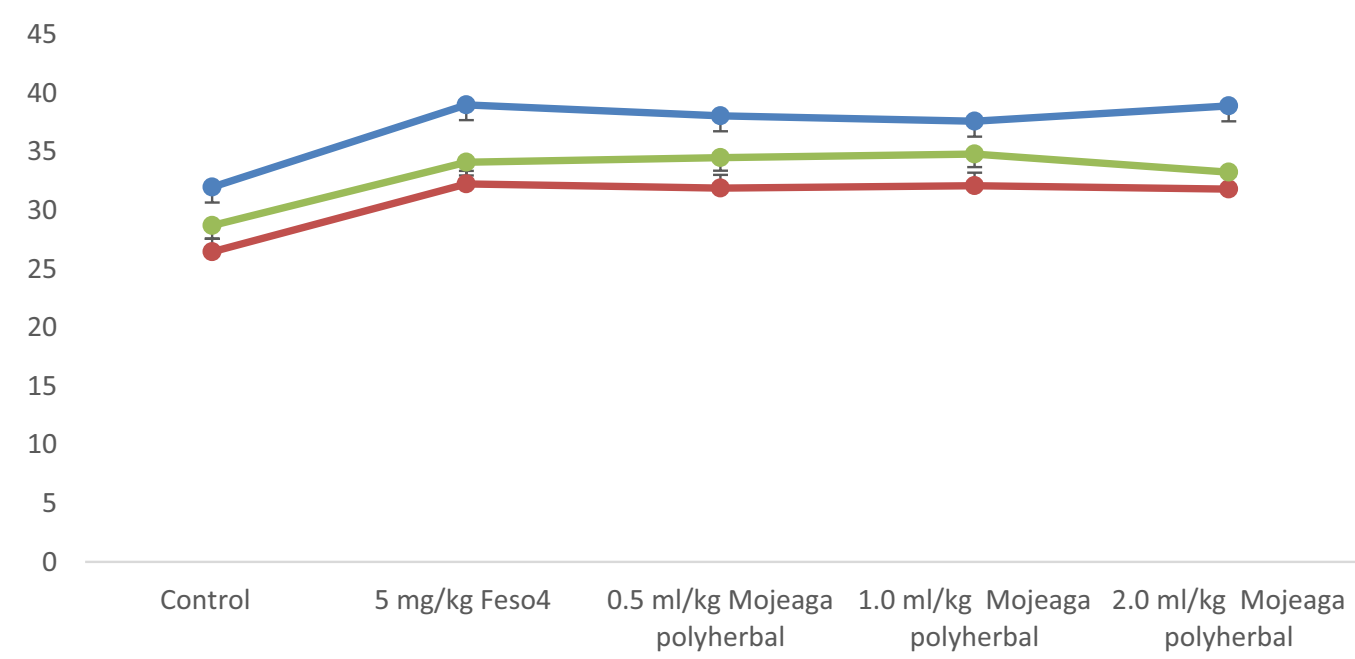

Fig. 17 Effect of Mojeaga herbal remedy on MCHC across various days in male rats ( $p<0.05)$. Blue: 1 days, Red: 5 days, Purple: 10 days, Y-axis: Mean Corpuscular Hemoglobin Concentration (g/d l), X-axis: groups/doses

Figures 15 and 16 showed a significant decrease in Mean Corpuscular Hemoglobin in $40 \mathrm{mg} / \mathrm{kg}$ Phenylhydrazine when compared with the increased observed in $10 \mathrm{mg} / \mathrm{kg}$ ferrous (iii) - hydroxide and treated groups (Mojeaga herbal remedy) in day 1 of the experiment with a specific significant increase in days 5 and 10 .

Figures 17 and 18 showed a significant decrease in Mean Corpuscular Hemoglobin Concentration in $40 \mathrm{mg} / \mathrm{kg}$ Phenylhydrazine when compared with the increased observed in $10 \mathrm{mg} / \mathrm{kg}$ ferrous (iii) - hydroxide and treated groups (Mojeaga herbal remedy) in day 1 of the experiment having subsequent increase in days 5 and 10 of the experiment (Figs. 19, 20).
As shown in Fig. 21, elicited slight significant increase in the $C D_{4}$ and $C D_{8}$ count as observed across the treatment groups when compared with the untreated control.

\subsection{Bone marrow anal rats fed with Mojeaga herbal remedy}

The administration of Mojeaga herbal remedy at graded doses induced a significant increase in the level of myeloerythroid cells ratio in the treatment groups $(60 \%$ for $0.5 \mathrm{ml} / \mathrm{kg}, 65 \%$ for $1 \mathrm{ml} / \mathrm{kg}$ and $85 \%$ for $2 \mathrm{ml} / \mathrm{kg}$ ) in male animals and $5 \mathrm{mg} / \mathrm{kg}$ of ferrous (iii) - hydroxide-induced myelo-erythroid cells with (60\% regeneration of the cells) specifically in day 10 when compared with untreated 


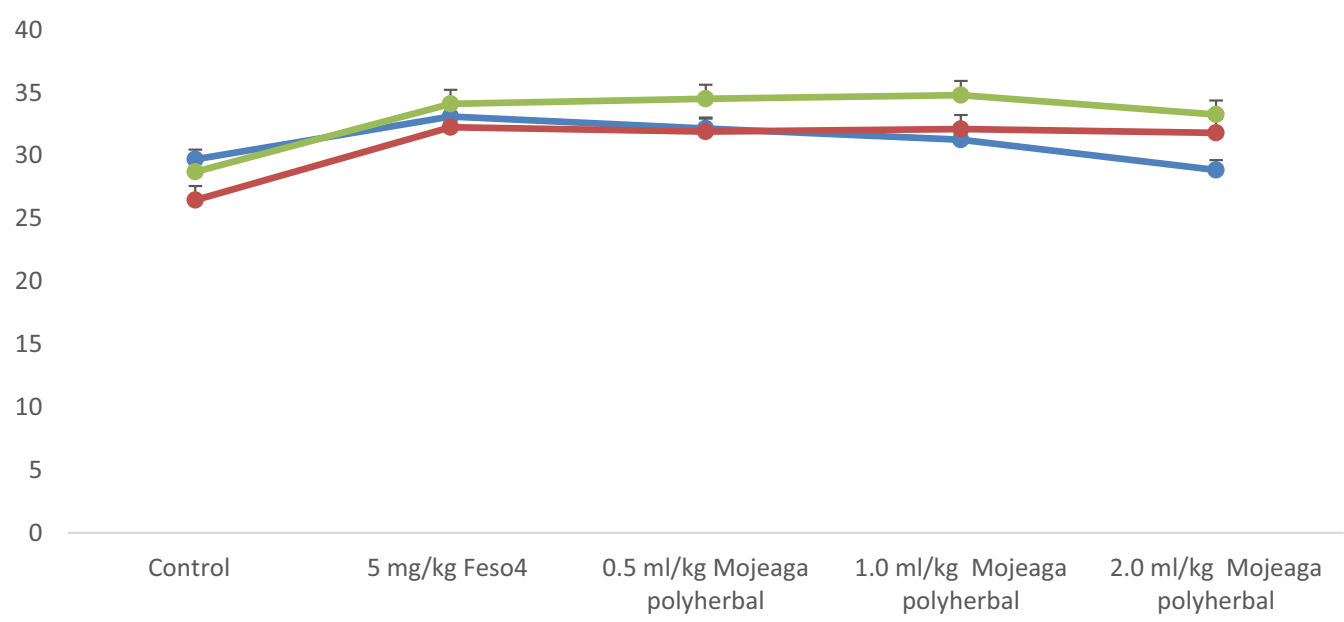

Fig. 18 Effect of Mojeaga herbal remedy on MCHC across various days in female rats ( $p<0.05)$. Blue: 1 days, Red: 5 days, Purple: 10 days, Y-axis: Mean Corpuscular Hemoglobin Concentration (g/d I), X-axis: groups/doses

control, which excited the released of mild myeloerythroid cells ratio $<40 \%$, hence showed severe anemic condition in the rats. The administration of Mojeaga herbal remedy at graded doses induced myelo-erythroid cells in female animals with a significant increase in the treatment groups $(0.5,1.0$ and $2.0 \mathrm{ml} / \mathrm{kg})$ at $(55,65$ and $90 \%$ ) and $5 \mathrm{mg} / \mathrm{kg}$ of ferrous (iii)-hydroxide-induced myelo-erythroid cells with a significant increase of (65\%) majorly in day 10 when compared with Distilled water induced myelo-erythroid cells with $<40 \%$ of $40 \mathrm{mg} / \mathrm{kg}$ phenyl hydrazine $\mathrm{HCl}$ group, thurs this is an indication of severe anemia in the rats.

\section{Discussion}

The Preliminary phytochemical screening of the product showed the presence of flavonoids, alkaloids, tannins, saponins, cardiac glycosides, phenols, terpenoids and steroids [35-38]. The literature has reported same phytochemicals in $A$. djalonensis root extracts in previous study. Antioxidant phytochemicals such as polyphenols, flavonoids, tannins and alkaloids have been documented for their effects on blood cells regenerations in animals $[39,40]$ and could have an indirect action to stimulate the hypothalamus and pituitary glands thereby influencing erythropoietin in the kidney to further triggered myeloerythroid cells in the bone marrow [41]. The Plant phytochemical constituent's includes flavonoids, alkaloids, tannins, saponins, cardiac glycosides, phenols, terpenoids and steroids are present in the product except the absent of steroids that is absent as shown in Tables 1 and 2 [40].

The result showed a significant increase in in vitro antioxidant activity of Mojeaga herbal remedy in DPPH, total antioxidant capacity and ferric reducing antioxidant potential radicals, when comparable with ascorbic acid. This could be responsible via scavenging oxidative stress capable of hemolyzing blood cell, hence mojeaga herbal remedy aid red blood cell regeneration as shown in Fig. 1, 2 and 3. This result is also in concordance with the findings of Muanya and Odukoya [42] that showed that high lipid peroxidation inhibition effect of Anthocleista djalonensis root extract in the raw and cooked fish homogenate among all the selected herbs enhancer in traditional medicine. Reactive oxygen species (ROS) are implicated in the pathogenesis of anemia. Overproduction of ROS in blood cells can affect its production; hence, plasma antioxidant defense mechanism prevents oxidative stress damage [43]. Antioxidants scavenge free radicals from the system and protect erythrocyte cells that are essential in blood formations. The antioxidant property of Mojeaga herbal remedy showed that it could possess the capacity to scavenge excess reactive oxygen species (ROS) in erythrocyte synthesis which handle oxidative damage of blood cells.

GC-MS analysis of Mojeaga herbal remedy revealed the presence of thirty-two phytochemicals (Tables 3, 4 and Fig. 4) with numerous biological properties. Several compounds such as Disulfide, dimethyl, 2-Methoxy-4-vinylphenol, 1-Dodecanol, 10-Phenyldecanoic acid, 8-Phenyloctanoic acid, n-Hexadecanoic acid and 15-Hydroxypentadecanoic acid are known for their antioxidant properties [44]. Previous studies showed that pyrogallol increased hydrogen peroxide $\left(\mathrm{H}_{2} \mathrm{O}_{2}\right)$ resistance linked to the reduction in intracellular oxidation and protein carbonylation [45]. Several compounds showed their antioxidant, antianemic, 

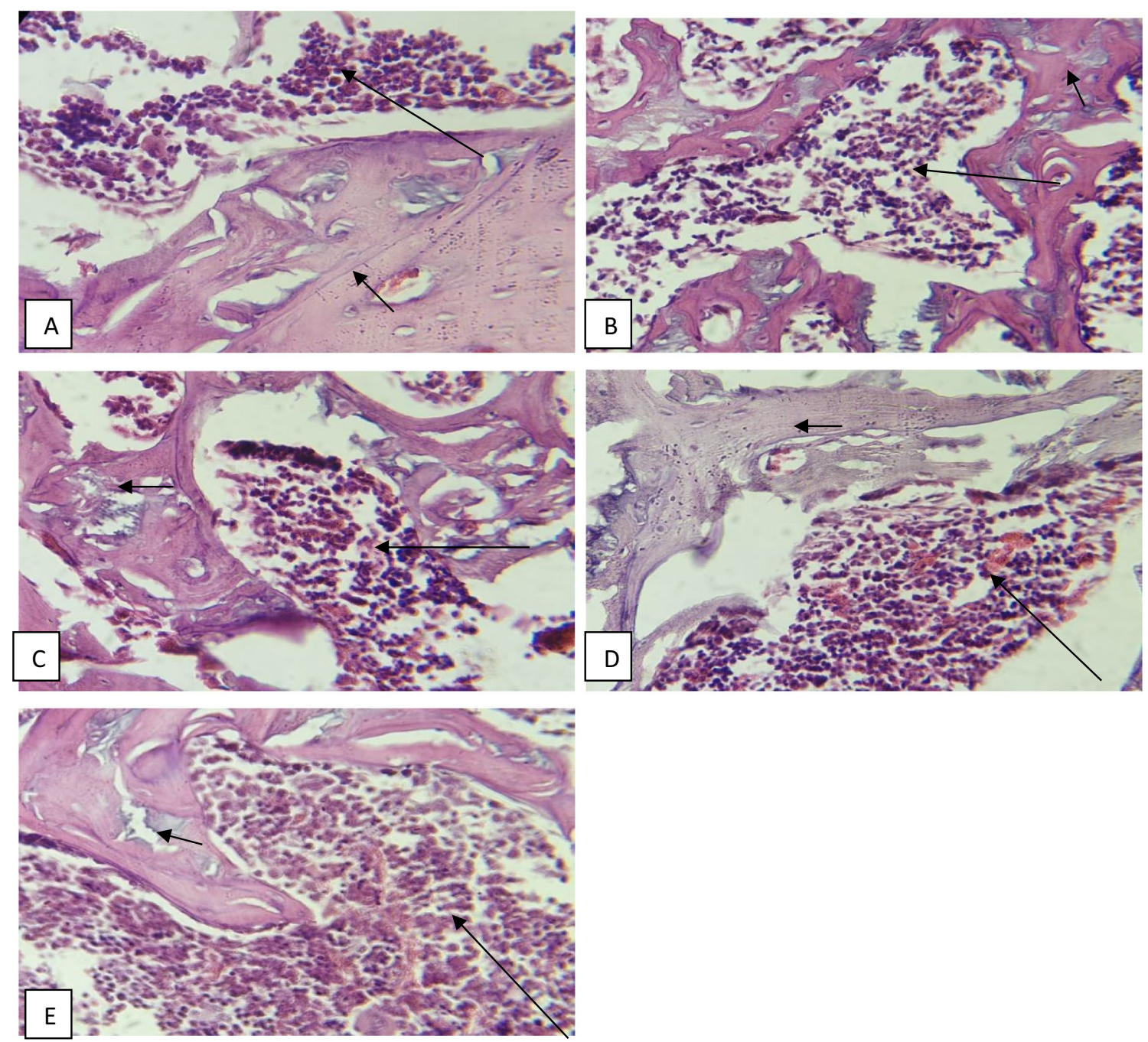

Fig. 19 Effect of Mojeaga herbal remedy on Myelo-Erythroid Cell in male rats. A Untreated group: the bone marrow cavity shows visible marrow cells, (long arrow). Visible histologic appearance for cartilage and bone trabeculae (short arrow). B $5 \mathrm{mg} / \mathrm{kg}$ Folic acid: The bone marrow cavity shows marrow cells, (long arrow). Visible histologic appearance for cartilage and bone trabeculae (short arrow). C $0.5 \mathrm{ml}$ Mojeaga herbal remedy: The bone marrow cavity shows visible marrow cells, (long arrow) with prominent fat cells (medium arrow). Visible histologic appearance for cartilage and bone trabeculae (short arrow). D $1.0 \mathrm{ml}$ Mojeaga herbal remedy: The bone marrow cavity shows visible slightly increased marrow cells, (long arrow). Visible histologic appearance for cartilage and bone trabeculae (short arrow). E $2.0 \mathrm{ml}$ Mojeaga herbal remedy: The bone marrow cavity shows increased marrow cells, (long arrow). Visible histologic appearance for cartilage and bone trabeculae (short arrow)

antiseptic, antibacterial, anti-dermatic, fungicide, pesticide. 9, 12-Octadecadienoic acid, methyl ester a major contributor of antioxidant and other potent biological activity of the product. Previous report by Yu, et al. [46] and Abubakar et al. [47] showed that 9, 12-octadecadienoic acid (Z, Z)-, methyl ester from chloroform extract of Albizia adianthifolia (Schumach) impeded cell proliferation and microbial growth. This unsaturated fatty acid in Mojeaga herbal remedy could be a factor for its antimicrobial, antioxidant and anti-inflammatory property of the products reported ethnomedicinally.
The n-Hexadecanoic acid is an ester derivative, with a strong antioxidant property, which elicited anticancer, anti-microbial, anti-haemolytic, antianemic, anti-diabetic and pesticidal inhibitory action of 5- $\alpha$ reductase activity [48]. Studies by Sudha et al. [49] showed that hexadecanoic acid, methyl ester have antioxidant, hypocholesterolemic, antiarteriosclerotic and anti-coronary properties. These potent compounds may be sole responsible as an antioxidant property of Mojeaga herbal remedy toward DPPH, total antioxidant capacity and FRAP radicals. The whole antioxidant 

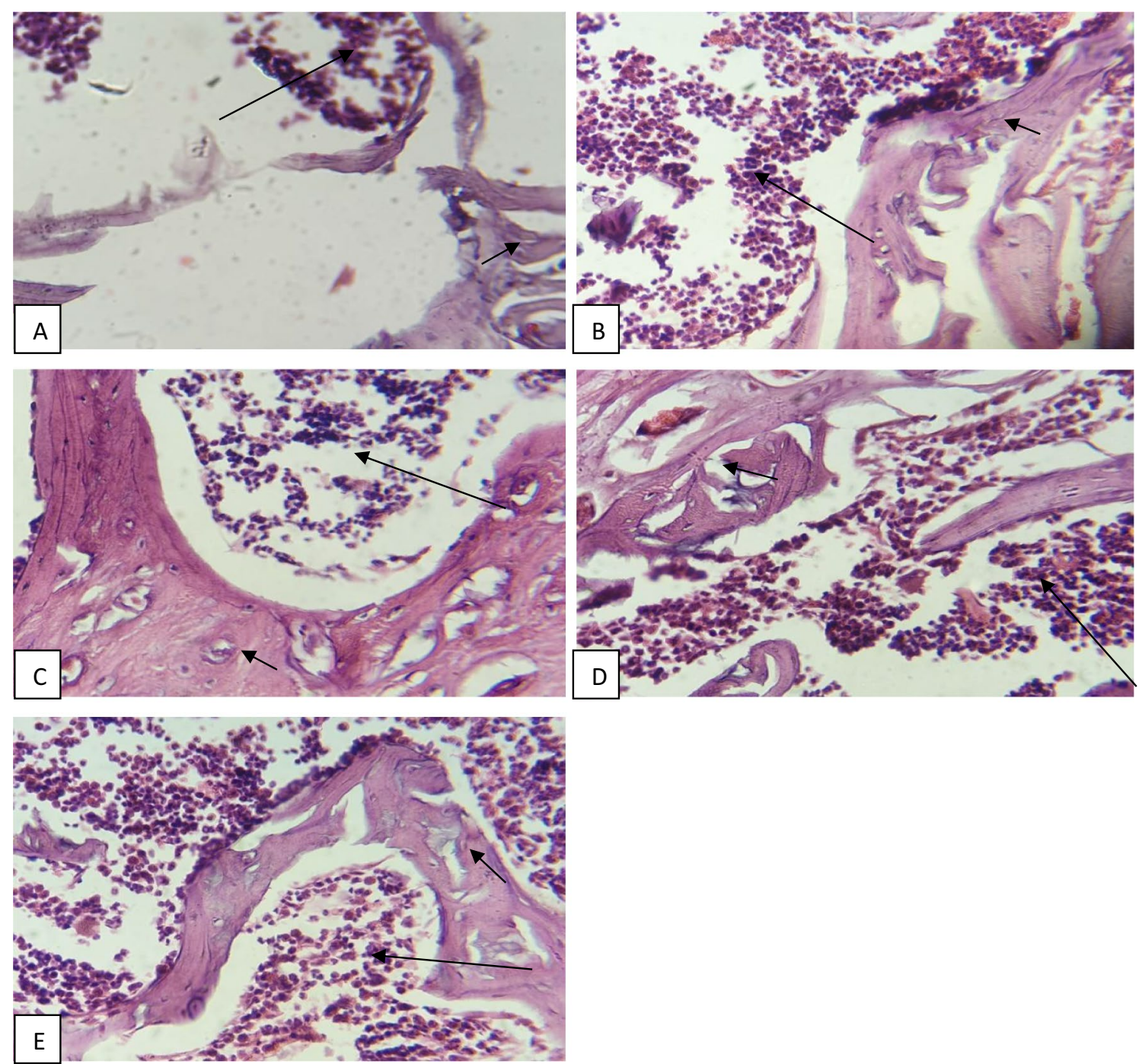

Fig. 20 Effect of Mojeaga herbal remedy on Myelo-Erythroid Cell in male rats. A Untreated group: The bone marrow cavity shows visible depleted scanty marrow cells, (long arrow) with not so remarkable histologic appearance for cartilage and bone trabeculae (short arrow). B 5 mg/kg Folic acid: The bone marrow cavity shows visible marrow cells, (long arrow). Visible histologic appearance for cartilage and bone trabeculae (short arrow). C $0.5 \mathrm{ml}$ Mojeaga herbal remedy: The bone marrow cavity reduced visible marrow cells, (long arrow). Visible histologic appearance for cartilage and bone trabeculae (short arrow). D $1.0 \mathrm{ml}$ Mojeaga herbal remedy: The bone marrow cavity shows visible marrow cells, (long arrow). Visible histologic appearance for cartilage and bone trabeculae (short arrow). E $2.0 \mathrm{ml}$ Mojeaga herbal remedy: The bone marrow cavity shows increased marrow cells, (long arrow). Visible histologic appearance for cartilage and bone trabeculae (short arrow)

phyto-components isolated from the product via $\mathrm{GC}-$ MS analysis could be liable for an increased in erythrocyte regeneration, as observed from this study.

Anti-anemic study showed Mojeaga herbal remedy enhanced blood production in the treatment groups across male and female animals [50]. Result from the red blood cell and its components (Hgb, HCT, RBC, $\mathrm{MCHC}, \mathrm{MCV}$ and $\mathrm{MCH}$ ) showed a significant increase across the treatment groups of male and female rat at day $10(18.05 \pm 1.35,51.40 \pm 3.50$ and $7.34 \pm 0.35)$ and
$(16.60 \pm 0.10,48.05 \pm 0.15$ and $6.78 \pm 0.36)$ when compared with untreated group (phenylhydrazine hydrochloride) $(13.69 \pm 2.62,39.95 \pm 7.95$ and $5.14 \pm 0.59$ for male animals) and (12.67 $\pm 2.54,36.72 \pm 7.39$ and $5.79 \pm 1.27$ for female) $(p<0.05)$ as shown in Fig. 5-18. Anemia was treated at days 1,5 and 10 using $10 \mathrm{mg} / \mathrm{kg}$ ferrous (iii)-hydroxide as reference drug and Mojeaga polyherbal preparation in graded concentration $(0.5,1.0$ and $2.0 \mathrm{ml} / \mathrm{kg}$ ) as reported by Yakubu et al. [51]. The recovery effect of blood cells probably could be as a result of 


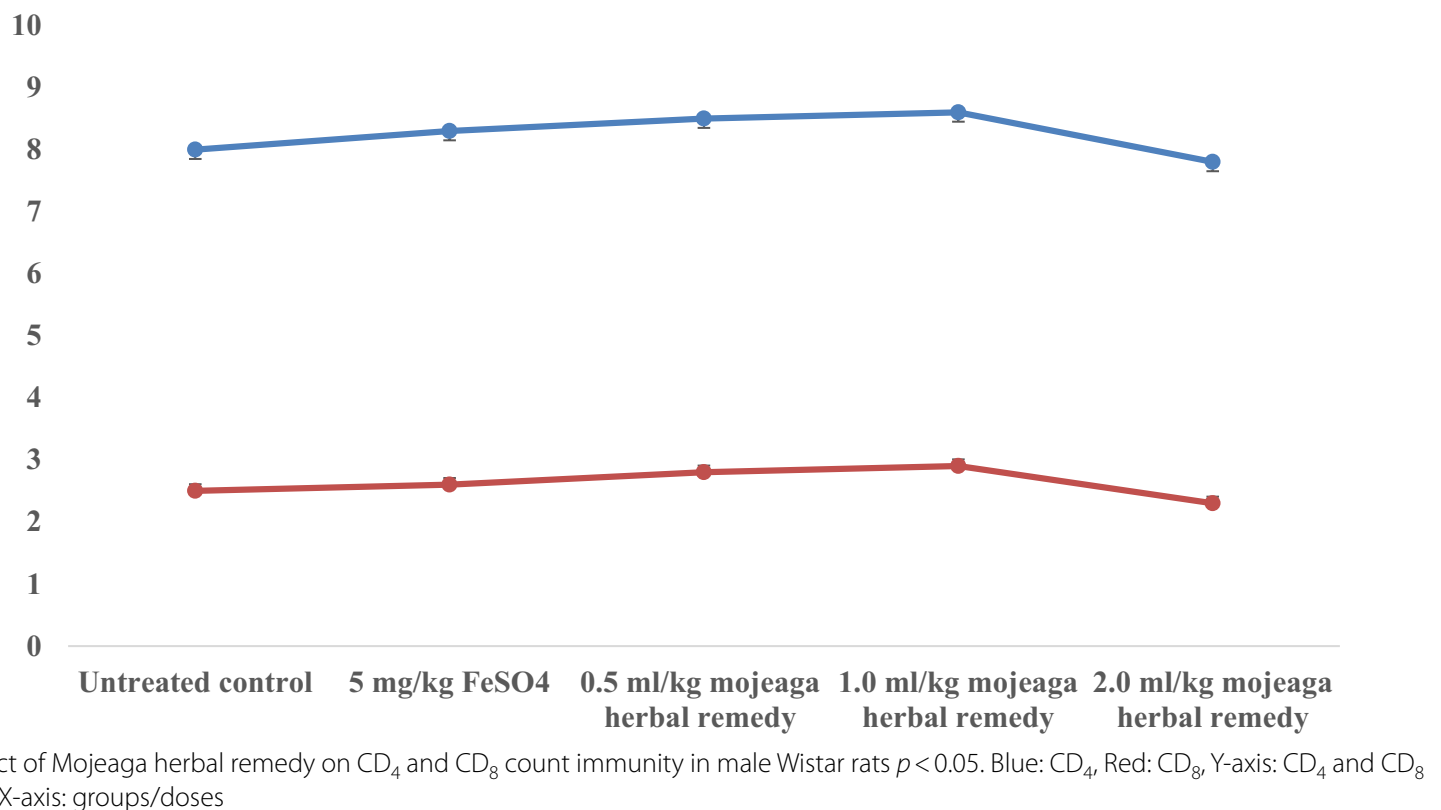

Fig. 21 Effect of Mojeaga herbal remedy on $C D_{4}$ and $C D_{8}$ count immunity in male Wistar rats $p<0.05$. Blue: $C D_{4}$, Red: $C D_{8}, Y$-axis: $C D_{4}$ and $C D_{8}$ $\left(\right.$ cells $\left./ \mathrm{mm}^{3}\right)$, X-axis: groups/doses

the mechanism of action from erythropoiesis in liver, stimulating the bone marrow to regenerate blood cells. Hemogloblin (oxygen carrying capacity of the blood), $\mathrm{MCV}, \mathrm{MCH}$ and $\mathrm{MCHC}$ exhibited a significant increase in the treated groups; this finding concurs with the work of Cole, [52] and Adebayo et al. [53] on ethanol extract of Bougainvillea spectabilis; [51,54] on the aqueous extracts of Fadogia arggrestis stem and Bulbine natalensis stem. The bone marrow elicited viable structures when preexposed to aqueous Mojeaga herbal remedy, triggers myelo-erythroid cells ratio with an increase 60\%, 65\% and $85 \%$ across the treated groups of male and female animals when compared with reference drug of male and female animals (60\%) M. E (myelo-erythroid cells) cells ratio having normal blood cells regeneration. Less than $40 \%$ M. E cells ratio for untreated group (phenylhydrazine hydrochloride) showed severe anemic state. These findings consent with the earlier report from Sen et al. [41] and Claro et al. [39] on the significant alteration and increase in red blood cells percentage and myelo-erythroid cells ratio formulation.

Findings from the Immunomodulatory studies elicited that pre-administration of Mojeaga herbal remedy displayed base line data with scientific proof on the Immunoprotective potential associated with herbal remedy as shown in Fig. 19. The parameters such as white blood cell count and its differential count were analyzed in comparison with the control and the treated groups showed that the treated groups' significant increase in white blood cells and its differentials count compared to the control. The study also showed that the $\mathrm{CD} 4$ and $\mathrm{CD}_{8}$ count had slight significant difference; hence, this served as an evident that aqueous Mojeaga herbal remedy possibly trigger humoral immune feedback because of its Immunoprotective property displayed.

\section{Conclusions}

It is significant to consider this research study which elicited essential preclinical information progressing to anti-anemic herbal remedy development in the country. Therefore, possible isolation and feature of bioactive component (s) should be accounted for with diverse pharmacological properties of Mojeaga herbal remedy in accordance with determine its bioactive guide to assay.

\section{Abbreviations}

GC-MS: Gas chromatography mass spectroscopy; DPPH: Diphenyl-1-picrylhydrazyl; FRAP: Ferric chloride reducing antioxidant power; EDTA: Ethylenediaminetetraacetic acid; RBC: Red blood cells; HGB: Haemoglobin; HCT: Hematocrit; MCV: Mean corpuscular volume; MCH: Mean corpuscular hemoglobin; MCHC: Mean corpuscular hemoglobin concentration.

\section{Acknowledgements}

Our earnest gratitude goes to Mr. Dialect and Mr. Ehigie of the Department of Haematology University of Benin Teaching Hospital, Mr. Odega Kelvin and Mrs. Queen Okoro of the Department of Morbid Anatomy, University of Benin Teaching Hospital the slides preparation and interpretation. Dr. Agu for the antioxidant assays in the Department of Medical Biochemistry, University of Benin.

\section{Authors' contributions}

Ml contributed to conceptualization, supervision, project administration; MOA contributed to investigation, formal analysis; MOA contributed to investigation, formal analysis; BOG contributed to methodology, investigation, writing - original draft and editing. All authors read and approved the final manuscript. 


\section{Funding}

None.

\section{Availability of data and materials}

Data obtained from this study were analyzed as shown across the various Tables and Figures. The materials used for this study such as chemicals, medicine, kits and experimental animals were procured from the different designated stores within and outside the country.

\section{Declarations}

\section{Ethical approval and consent to participate}

All procedures using animals obtained the approval of Life Sciences Institutional Animal Ethical Committee, University of Benin with LS19214 ethical number.

\section{Consent for publication}

Not applicable.

\section{Competing interests}

No competing interests.

\section{Author details}

'Phytomedicine Unit, Department of Plant Biology and Biotechnology, University of Benin, PMB 1154, Benin City, Edo State, Nigeria. ${ }^{2}$ Mojeaga International Ventures Ltd, Flat 75, Block H, Federal Housing Estate, Ikpoba Hill, Benin City, Edo State, Nigeria.

Received: 28 October 2021 Accepted: 1 February 2022

Published online: 21 February 2022

\section{References}

1. Lewis WH (2003) Medicinal botany: Plants Affecting Human Health. John Willey \& Sons 978

2. Nostro A, Germano MP, D'Angelo V, Marino A, Cannatelli MA (2000) Extraction methods and bioautography for evaluation of medicinal plant antimicrobial activity. Lett Appl Microbiol 30:379-384

3. Moghadamtousi SZ, Rouhollahi E, Karimian H, Fadaeinasab M, Abdulla MA, Kadir HA (2014) Gastroprotective activity of Annona muricata leaves against ethanol-induced gastric injury in rats via Hsp70/Bax involvement. Drug Des Dev Ther 8:2099-2111

4. Moghadamtousi S, Fadaeinasab M, Nikzad S, Mohan G, Ali H, Kadir $H$ (2015) Annona muricata (Annonaceae): a review of its traditional uses, isolated acetogenins and biological activities. Int J Mol Sci 16:15625-15658

5. Al-Daihan S, Al-Faham M, Al-shawi N, Almayman R, Brnawi A, Zargar S, Bhat RS (2013) Antibacterial activity and phytochemical screening of some medicinal plants commonly used in Saudi Arabia against selected pathogenic microorganisms. J King Saud Univ Sci 25:115-120

6. Webster GL (2014) Euphorbiaceae. In: Kubitzki K (Ed) The families and genera of vascular WHO manual of basic techniques for a health laboratory 1991

7. Timibitei K, Alikwe P, Wekhe S, Ohimain E (2013) Effects of Alchornea Cordifolia root bark, seeds and pod husks on the growth response and visceral organs of rabbits. Nig J Agric Food Environ 9:23-27

8. Adejuwon AA, Adekunle IO, Ismail OI, Hassanat AK (2014) Evaluation of the anti-arthritic activity of the hydroethanolic leaf extract of alchornea cordifolia in rats. Afr J Tra Comple Altern Med 11:402-410

9. Kwabena J (2012) Combining natural reaction analogues and first derivative spectrophotometrie method to enhance the visible spectra of a non polar crude leaf extract. Am J Exp Agric 2:207-218

10. Agyare C, Ansah A, Ossei P, Apenteng J, Boakye Y (2014) Wound healing and Anti-infective Properties of Myrianthus arboreus and Alchornea cordifolia. Med Chem 4:533-539

11. Philip CNA, Elijah IO, Amos EK (2014) Performance evaluation of New zealand white rabbits fed Alchornea cordifolia leaf meal as replacement for soya bean meal. Am J Agric For 2:51-54
12. Adeshina G, Kunle O, Onaolapo J, Ehinmidu J, Odama L (2012) Phytochemical and antibacterial studies of the hexane extract of Alchornea cordifolia Leaf. Phytochem Nutraceut 65(89):96

13. Dahlberg JA, Wilson JP, Synder T (2004) Alternative uses of sorghum and pearl millet in Asia. In: Proceedings of an expert meeting, ICRISAT, Patancheru, Andhra Pradesh, India, 1-4 July, 2003, 2004

14. Makokha AO, Oniango RK, Njoroge SM, Kinyanjui PK (2002) Effects of malting on protein digestibility of some Sorghum (Sorghum bicolour) varieties grown in Kenya. Afr J Foods Nutr Sci 2(2):168-175

15. Duke JA, Wain KK (1981) Medicinal plants of the World. In computer index more than 85,000 entries, 3 vols.

16. Owolagba GK, Avwioro OG, Oduola T, Adeosun OG, Enaowho TN, Wilson Jl, Ajumobi KO (2009) Histological observation of 24 h oral administration of the extract of Sorghum bicolor on albino rats. J Cell Anim Biol 3(1):001-003

17. Avwioro OG, Aloamaka CP, Olabampe OB, Oduola T (2006) Collagen and muscle stain obtained from Sorghum bicolor. Scand J Clin Lab Investig 66:161-168

18. Avwioro OG, Owolagba GK, Anibor E, Bankole JK, Oduola T, Adeosun OG, Aloamaka CP (2009) Biochemical observations in Wistar rats fed with the histological dye extracted from Sorghum bicolor. Int J Med Med Sci 1(10):464-546

19. Little M (2001) Health care rationing: constraints and equity. Med J Austr 174:641-642

20. Okonkwo JE, lyadi KC, Effiong CO (2004) Effect of chronic administration of haematological parameters of rats. Nig J Physiol Sci 19(1-2):10-13

21. Gulia SK, Wilson JP, Carter J, Singh BP (2007) Progress in grain pearl millet research and market development. In: Janick J, Whipkey A (eds) Issues in new crops and new uses. ASHS Press, Alexandria, pp 196-203

22. Kajuna S (2001) Millet: post-harvest operations. Sokoine Univ. of Ag., Morogoro, Tanzania. D. Mejia and B. Lewis (ed.) FAO. http://www.fao.org/ inpho/inpho-post-harvest-compendium/cereals-grains/en/. Accessed 08 Aug 2014

23. Kachare DP, Chavan JK, Kadam SS (1994) Nutritional quality of some controlled cow pea. Plants Foods Hum Nutr 38(2):155-162

24. Fasidi DA, Gbeassor M, Vovor A, Eklu-Gadegbeku K, Aklikokon K, Agbonon A (2008) Effect of Tectona grandis on phenyl hydrazine-induced anaemia in rats. Fitoterapia 79(5):332-336

25. Duff S (2011) Types of Anaemia. www.innvista.com

26. Ogbe RJ, Adoga Gl, Abu AH (2010) Antianemic potentials of some plant extracts on phenyl hydrazine-induced anaemia in rabbits. J Med Plants Res 4(8):680-684

27. Akinkugbe OF (1991) Anaemia: the perils of plenty. Clin Pharmaceu Herbal Med 18:15-19

28. Sharda S, Shukla A, Singh CS, Bigoniya P (2011) A review on Herbal Antianaemia plants RGI. Intern J Appl Sci Technol 4:26-68

29. Sofowora A (1993) Medicinal plants and traditional medicinal in Africa. Screening plants for bioactive agents (2nd Ed.). Sunshine House, Ibadan, Nigeria: Spectrum Books Ltd; pp 134-156

30. Trease GE, Evans WC (2002) Pharmacognosy. 15th Ed. London: Saunders Publishers; 42-44, 221-229, 246-249, 304-306, 331-332, 391-393

31. Mensor L, Menezes FS, Leitao GG, Reis AS, dos Santos C, Coube CS, Leitao SG (2001) Screening of Brazilian plant extracts for antioxidant activity by the use of DPPH free radical method. Phytothe Res 15:127-130

32. Pisoschi AM, Negulescu GP (2011) Methods for total antioxidant activity determination: a review. Biochem AnalyBiochem 1(1):25-52

33. Mervat MM, Far E, Hanan A, Taie A (2009) Antioxidant activities, total anthrocynins, phenolics and flavonoid contents of some sweet potato genotypes under stress of different concentration of sucrose and sorbitol. Austr J Basic Appl Sci 3(4):3609-3616

34. Ruch RJ, Cheng SJ, Klaunig JE (1989) Prevention of cytotoxicity and inhibition of intracellular communication by antioxidant catechins isolated from Chinese green tea. Carcinogenesis 10:1003-1008

35. Baris O, Gulluce M, Sahin F, Ozer H, Kilic H, Ozkan H, Sokmen M, Ozbeck T (2006) Bioloical activities of the essential oil and methanol extract of Achillea biebersteinii Afan (Asteraceae). Turkish J Biol 30:65-73

36. World Health Organization (WHO) (2013) WHO traditional medicine strategy: 2014-2023. World Health Organization, Geneva

37. Sati SC, Joshi S (2011) Aspects of antifungal potential of ethnomedicinally known medicinal plants. Res J Med Plants 5:377-391 
38. Okeke CU, Chinelo AE, Ekwuonye BC, Onwubiko VC, Udechukwu CD, Aziagba BO (2015) Comparative study of proximate and phytochemical compositions of Anthocleista Djalonensis Planch. And Anthocleista Vogelii A. Chev. (Longaniaceae) In South Eastern Nigeria. Intern J Sci Technol 4(7):377-379

39. Claro LM, Leonart MS, Comar SR, Do AJ (2006) Nascimento, effect of vitamin $C$ and $E$ on oxidative processes in human erythrocytes. Cell Biochem Funct 24:531-535

40. Sahreen S, Khan MR, Khan RA, Shah NA (2013) Effect of Carissa opaca leaves extract on lipid peroxidation, antioxidant activity and reproductive hormones in male rats. Lipids Health Dis 12:90

41. Sen G, Mandal S, Saha RS, Mukhopadhyay S, Biswas T (2005) Therapeutic use of quercetin in the control of infection and anaemia association with visceral leishmaniasis. Free Radical Biol Med 38:1257-1264

42. Muanya CA, Odukoya OA (2008) Lipid peroxidation as index of activity in aphrodisiac herbs. J Plant Sci 3(1):92-98

43. Agarwal A, Said TM (2003) Role of sperm chromatin abnormalities and DNA damage in male infertility. Hum Reprod 9:331-345

44. Leonardo S, Craig F, Silvia G (2001) Hydroxycinnamic acids as natural antioxidants. RICHMAC Magazine 83:1-4

45. Vanda M, Vilaça R, de Freitas V, Moradas FP, Mateus N, Costa V (2015) Effect of myricetin, pyrogallol, and phloroglucinol on yeast resistance to oxidative stress. Oxid Med Cell Longev. https://doi.org/10.1155/2015/782504

46. Yu FR, Lian XZ, Guo HY, McGuire PM, Li RD (2005) Isolation andcharacterization of methyl esters and derivatives from Euphorbia kansui(Euphorbiaceae) and their inhibitory effects on the human SGC7901 cells. J Pharm Pharmaceut Sci 8:528-535

47. Abubakar MN, Majinda RRT (2016) GC-MS Analysis and preliminary antimicrobial activity of Albizia adianthifolia (Schumach) and Pterocarpus angolensis (DC). Med (Basel) 3(1):3

48. Chandrasekaran M, Senthilkumar A, Venkatesalu V (2011) Antibacterial and antifungal efficacy of fatty acid methyl esters from leaves of Sesuvium portulacastrum L. Eur Rev Med Pharmacol Sci 15(7):775-780

49. Sudha T, Chidambarampillai S, Mohan VR (2013) GC-MS analysis of bioactive components of aerial parts of Fluggea lucopyrus Willd (Euphorbiaceae). J Appl Pharmaceut Sci 3:126-130

50. Yamoto O, Maude Y (2002) Susceptibility to onion-induced hemolysis in dogs with hereditary high erythrocyte reduced glutathione and potassium concentrations. Am J Veter Res 53(1):134-142

51. Yakubu MT, Akanji MA, Oladiji AT (2007) Haematological evaluation in male albino rats following chronic administration of aqueous extract of Fadogia argrestis stem. Pharmacog Mag 3:34-47

52. Cole EH (2006) Veterinary clinical pathology'. W. B. Sander, Philadelphia, USA, 10-42

53. Adebayo JO, Adesokan AA, Olatunji LA, Buoro DO, Soladoye AO (2005) Effect of ethanolic extract of Bougainvillea spectabilis leaves on haematological and serum lipid variables in rats. Biochemistry 17:45-70

54. Yakubu MT, Afolayan AJ (2009) Effect of aqueous extract of Bulbine natalensis Baker stem on haematological and serum lipid profile of male wistar rats. Indian J Exp Biol 47:283-288

\section{Publisher's Note}

Springer Nature remains neutral with regard to jurisdictional claims in published maps and institutional affiliations.

\section{Submit your manuscript to a SpringerOpen ${ }^{\circ}$ journal and benefit from:}

- Convenient online submission

- Rigorous peer review

- Open access: articles freely available online

- High visibility within the field

- Retaining the copyright to your article 